\title{
Multiphase Flow and Multicomponent Reactive Transport Model of the Ventilation Experiment in Opalinus clay
}

\author{
L. Zheng ${ }^{1 *}$, J. Samper ${ }^{1 \#}$, L. Montenegro ${ }^{1}$, J.C. Mayor ${ }^{2}$ \\ ${ }^{1}$ E.T.S. Ingenieros de Caminos, Canales y Puertos, Universidad de Coruña, Campus de Elviña \\ s/n 15192 La Coruña, Spain \\ ${ }^{2}$ ENRESA, Emilio Vargas 7, 28043 Madrid, Spain \\ * Present address: Lawrence Berkeley National Lab, 1 Cyclotron Rd, Berkeley, CA, 94720, USA \\ ${ }^{\#}$ Corresponding author. E-mail address: jsamper@udc.es (J. Samper)
}

\begin{abstract}
During the construction and operational phases of a high-level radioactive waste (HLW) repository constructed in a clay formation, ventilation of underground drifts will cause desaturation and oxidation of the rock. The Ventilation Experiment (VE) was performed in a $1.3 \mathrm{~m}$ diameter unlined horizontal microtunnel on Opalinus clay at Mont Terri underground research laboratory in Switzerland to evaluate the impact of desaturation on rock properties. A multiphase flow and reactive transport model of VE is presented here. The model accounts for liquid, vapor and air flow, evaporation/condensation and multicomponent reactive solute transport with kinetic dissolution of pyrite and siderite and local-equilibrium dissolution/precipitation of calcite, ferrihydrite, dolomite, gypsum and quartz. Model results reproduce measured vapor flow, liquid pressure and hydrochemical data and capture the trends of measured relative humidities, although such data are slightly overestimated near the rock interface due to uncertainties in the turbulence factor. Rock desaturation allows oxygen to diffuse into the rock and triggers pyrite oxidation, dissolution of
\end{abstract}


calcite and siderite, precipitation of ferrihydrite, dolomite and gypsum and cation exchange. $\mathrm{pH}$ in the unsaturated rock varies from 7.8 to 8 and is buffered by calcite. Computed changes in the porosity and the permeability of Opalinus clay in the unsaturated zone caused by oxidation and mineral dissolution/precipitation are smaller than 5\%. Therefore, rock properties are not expected to be affected significantly by ventilation of underground drifts during construction and operational phases of a HLW repository in clay.

Keywords: Ventilation Experiment, multiphase flow, reactive transport, Opalinus clay, Mont Terri, pyrite oxidation

\section{Introduction}

Clay formations have been selected as candidate host rocks for high-level radioactive waste (HLW) disposal in deep geological repositories. Underground drifts will be subjected to ventilation during the construction and operational phase of a HLW repository. If carried out over significant periods of time, ventilation could cause desaturation of the rock adjacent to the drifts which in turn could have a detrimental effect on physical and geochemical rock properties. The Ventilation Experiment (VE) test was performed at the Mont Terri underground research laboratory (Switzerland) to investigate and evaluate the potential impact of ventilation on hydraulic, mechanical and chemical conditions of consolidated Opalinus clay (Mayor et al., 2005). Mayor et al. (2007) presented a hydromechanical model of VE using CODE_BRIGHT (Olivella et al., 1996). This model which accounts for evaporation at the rock-air interface led to the conclusion that thermal and hydraulic rock characteristics will not be affected significantly by ventilation except in a narrow ring around the surface of the tunnel having a thickness smaller than $30 \mathrm{~cm}$ where saturation degree of the rock is smaller than 95\%. Mayor et al. (2007) documented uncertainties in the turbulence factorused to quantify vapor flux at the rock-air interface. Mayer et al. (2007) 
presented a two-phase flow model of VE which was solved with TOUGH2 (Pruess et al., 1999) and used it to derive the hydraulic properties of the excavation damaged zone (EDZ) and Opalinus clay. They found that rock desaturation extends up to a radial distance of about $1.35 \mathrm{~m}$ from the tunnel wall. The driest zone having saturation degrees smaller than $95 \%$ has a thickness of $40 \mathrm{~cm}$ measured from the tunnel wall. Mayer et al. (2007) determined also that EDZ matrix permeability does not differ strongly from that of undisturbed rock. Fernández-García et al. (2007) presented a hydrogeological model of VE using MODFLOW (McDonald and Harbaugh, 1984) to estimate effective regional-scale hydraulic conductivity of Opalinus clay taking into account EDZ and rock desaturation.

There are numerous studies of pore water chemistry in Opalinus clay at Mont Terri (Pearson et al., 2003). Their results show that desaturation of Opalinus clay by ventilation causes pyrite oxidation and dissolution/precipitation of mineral phases. However, there are no reported models of desaturation and geochemistry in Opalinus clay.

A multiphase flow and multicomponent reactive transport model of VE is presented here. The multiphase flow model is based on the model of Mayor et al. (2007) and is calibrated with relative humidity, vapor flux and liquid pressure data. The reactive transport model is based on the geochemical model of Pearson et al. (2003) and is calibrated using mineralogical and aqueous extract data from Fernández et al. (2006). The inverse hydrochemical model of Zheng et al. (2008) is used to estimate the chemical composition of pore water of clay samples from aqueous extract data. The model is used to evaluate changes in porosity and permeability of the rock caused by mineral dissolution/precipitation. The paper starts by describing the main features of VE. Conceptual and numerical multiphase flow and reactive transport models of VE are then presented. Finally, model results are described and main uncertainties and conclusions are discussed.

\section{Ventilation Experiment}

VE was carried out in a $1.3 \mathrm{~m}$ diameter unlined horizontal microtunnel at Mont Terri underground laboratory in Switzerland. The microtunnel was excavated in 1999 within the shaly 
facies of the Opalinus formation. It runs subhorizontal in a NW-SE direction (with a dip of about $2^{\circ}$ towards SE) and is oriented perpendicular to the rock bedding strike (Mayor et al., 2007). A $10 \mathrm{~m}$ long section of the tunnel was sealed by two doors and subjected to several desaturation phases by prolonged ventilation (Figure 1). VE involved several ventilation and resaturation phases (Table 1). The first 3 phases included the background period which goes from microtunnel excavation in 1999 to the beginning of the controlled ventilation in June 2003. The following 3 phases corresponded to the first ventilation period which was divided into three stages with decreasing relative humidities (phases 4, 5 and 6). Phase 4 was used to achieve initial quasi-saturated conditions in the rock while phases 5 and 6 were intended to desaturate the rock with strong ventilation with dry air (Table 1). Rock resaturation took place during phases 7 and 8. Phase 9 of VE started on July 1, 2005 and corresponded to a second ventilation period.

The main objectives of VE include: 1) Estimation of desaturation and resaturation times in Opalinus clay by drift ventilation; 2) Estimation of saturated hydraulic conductivity of the rock; 3) Estimation of EDZ and its time evolution in terms of changes in hydraulic conductivity and displacements induced by drying; 4) Characterization of hydraulic properties of the rock under saturated and unsaturated conditions; 5) Geochemical characterisation of desaturated zone; and 6) Calibration and validation of hydromechanical and geochemical models (Mayor et al., 2005).

Ventilation was performed by circulating air with specified relative humidity, $R H_{\text {in }}$ and temperature, $T_{i n}$ at a flux rate $Q_{i n}$. Air was injected at one of the ends of the VE tunnel through an inflow pipe and evacuated at the other end of the test section with an outflow pipe. Values of $Q_{\text {out }}$, $R H_{\text {out }}$ and $T_{\text {out }}$ were measured in the outflow pipe by flow meters and temperature and relative humidity sensors. Values of $Q_{i n}, R H_{\text {in }}$ and $R H_{\text {out }}$ in each phase are listed in Table 1. Relative humidity and temperature of the air inside the test area were recorded with 4 hygrometers. The evaporation of free water was measured in 2 water pans. The rock around the VE section was instrumented up to a depth of about $2 \mathrm{~m}$ with 24 mini-piezometers, 16 capacitive hygrometers, 16 psychrometric hygrometers, 8 mini-extensometers and 5 electrode chains located in 9 cross-sections 
to monitor rock displacement, water potential, water content and temperature. Hydraulic and mechanical data were monitored during desaturation and saturation phases. Pore water chemical composition was measured at the end of desaturation phase 6 and resaturation phase 8 by aqueous extract tests (Fernández et al., 2006). Air temperature in the VE tunnel remained nearly constant around $15-16{ }^{\circ} \mathrm{C}$. A detailed discussion of the ventilation system and the monitoring system can be found in Mayor et al. (2005, 2007).

Several boreholes (BVE) were drilled on the rock around the VE for geochemical characterization at different phases. Boreholes BVE-85 and BVE-86 were drilled at the end of the first ventilation period (phase 6). After the resaturation period (phase 8) 5 boreholes BVE-96, BVE97, BVE-98, BVE-99 and BVE-100 were drilled inside the VE area while BVE-101 and BVE-102 were drilled outside the VE area (Figure 2). Most of these boreholes are horizontal and sub-parallel to the bedding. Only BVE- 85 has a vertically down orientation and BVE-100 is perpendicular to bedding. Borehole lengths range from 1.45 to $2 \mathrm{~m}$ and have a diameter of $8 \mathrm{~cm}$ (Fernández et al., 2006). Samples of the Opalinus clay from drillcores of boreholes BVE-97, BVE-99, BVE-100, BVE-101 and BVE-102 were collected at different depths to determine clay physico-chemical parameters. After drilling, drillcores were wiped to remove any drilling fluid on the core surfaces. Unaltered core samples were immediately packed in aluminum-foil bags, flushed with argon gas to displace atmospheric gases and sealed after applying vacuum. A second layer of aluminum-foil was placed and, finally, core samples were wrapped with air-evacuated and durable plastic bags to ensure full protection and prevent any loss of moisture before the laboratory chemical analyses. Once at CIEMAT laboratories in Madrid (Spain) samples were taken using a knife to avoid sampling the outer part disturbed by core drilling (Fernández et al., 2006).

Pore water chemical composition was obtained from aqueous extract tests (AET) performed on samples collected from boreholes BVE-97, BVE-99, BVE-100, BVE-101 and BVE-102 (Fernández et al., 2006). On the other hand, only chloride and sulphate data are available in boreholes BVE-85 and BVE-86 (Traber, 2004). 


\section{Multiphase flow and reactive transport model}

\subsection{Conceptual model}

\subsubsection{Fluid flow}

Water may flow in the liquid in response to a hydraulic gradient according to Darcy's Law and may also flow in the gaseous phase as water vapor due to air convection and a gradient in moisture content according to Fick's Law. The conceptual model takes into account: a) Advective flow of liquid water, b) Advective and diffusive flow of water vapor, c) Advective and diffusive flow of "dry" air, and d) Advective flow of air dissolved in the water. The general mass balance equation for water, air and heat is given by (Navarro and Alonso, 2000):

$$
\frac{\partial \mathrm{m}^{\mathrm{i}}}{\partial \mathrm{t}}=-\nabla \cdot \mathrm{q}_{\mathrm{tot}}^{\mathrm{i}}+\mathrm{r}^{\mathrm{i}}
$$

where $m$ and $q$ are the mass and the total mass flux of water $(\mathrm{i}=w)$, air $(\mathrm{i}=a)$, and heat $(\mathrm{i}=h)$, respectively, and $r$ is a source/sink tem. Total mass of water is given by

$$
m^{w}=\phi S_{l} \rho_{l} X_{l}^{w}+\phi S_{g} \rho_{g} X_{g}^{\mathrm{v}}
$$

while mass flux of water is computed from

$$
\mathrm{q}_{\mathrm{tot}}^{\mathrm{w}}=\rho_{\mathrm{l}} X_{1}^{\mathrm{w}} \mathrm{q}_{1}+\rho_{\mathrm{g}} X_{\mathrm{g}}^{\mathrm{v}} \mathrm{q}_{\mathrm{g}}+\mathrm{j}_{\mathrm{g}}^{\mathrm{v}}
$$

where $\phi$ is porosity, $S_{l}$ and $S_{g}$ are liquid and gas saturation degrees, respectively, $\rho$ is density, $X$ is mass fraction, $\boldsymbol{q}$ is Darcy velocity, and $\boldsymbol{j}$ is diffusive flux. Superscripts $w$ and $v$ denote water and vapor, respectively. Subscripts $l$ and $g$ denote liquid and gas phases, respectively. Mass $m^{a}$ and flux of air, $\boldsymbol{q}_{\text {tot, }}^{\mathrm{a}}$ are given by 


$$
\begin{aligned}
& m^{a}=\phi S_{l} \rho_{l} X_{l}^{a}+\phi S_{g} \rho_{g} X_{g}^{\mathrm{a}} \\
& \mathrm{q}_{\text {tot }}^{\mathrm{a}}=\rho_{\mathrm{l}} \mathrm{X}_{1}^{\mathrm{a}} \mathrm{q}_{1}+\rho_{\mathrm{g}} X_{\mathrm{g}}^{\mathrm{a}} \mathrm{q}_{\mathrm{g}}+\mathrm{j}_{\mathrm{g}}^{\mathrm{a}}
\end{aligned}
$$

Water and air fluxes are computed from

$$
\begin{gathered}
\mathrm{q}_{\mathrm{m}}=-\frac{\mathrm{K}_{\mathrm{im}} \mathrm{k}_{\mathrm{rm}}}{\mu_{\mathrm{m}}}\left(\nabla \mathrm{P}_{\mathrm{m}}+\rho_{\mathrm{m}} \mathrm{g} \nabla \mathrm{z}\right) \quad m=l, g \\
\mathrm{j}_{\mathrm{g}}^{\mathrm{n}}=-\mathrm{D}_{\mathrm{a}}^{\mathrm{v}} \nabla \mathrm{X}_{\mathrm{g}}^{\mathrm{n}} \quad \mathrm{n}=a, v
\end{gathered}
$$

where subscript $m$ applies to both liquid (l) and gas (g) phases, superscript $n$ refers to air (a) and vapor (v)components, $K_{i}$ is the intrinsic permeability tensor, $k_{r}$ is the relative permeability, $\mu$ is the viscosity, $P$ is the pressure, $g$ is the gravitational acceleration, $z$ is the vertical coordinate, and $\mathrm{D}_{\mathrm{a}}^{\mathrm{v}}$ is the vapor diffusivity tensor.

Evaporation is quantified with an approximate Dalton-type equation similar to that commonly used for modeling soil evaporation which involves a turbulence exchange factor (Ward Wilson et al., 1994). Usually, the turbulence factor increases linearly with wind velocity. Model results are highly dependent on the values adopted for the turbulence factor at the rock-air interface. Mayor et al. (2005) derived rough estimates for the turbulence factor from evaporation data recorded in two evaporation pans installed within the VE test section. The vapor flux at the rockatmosphere interface, $j_{g}^{w}\left(\mathrm{~kg} / \mathrm{m}^{2 /} \mathrm{s}\right)$, is computed with the following expression proposed by Velasco and Pedraza (2002):

$$
j_{g}^{w}=\beta_{g}\left[\left(\theta_{g}^{w}-\left(\theta_{g}^{w}\right)^{0}\right]\right.
$$


where $\theta_{g}^{w}$ is the vapor density at the rock surface $\left(\mathrm{kg} / \mathrm{m}^{3}\right),\left(\theta_{g}^{w}\right)^{0}$ is the vapour density in the atmosphere, and $\beta_{g}$ is the turbulence factor $(\mathrm{m} / \mathrm{s})$. This parameter was calibrated for each phase of the experiment (see Table 1).

\subsubsection{Solute Transport}

Multicomponent solute transport processes include: advection, molecular diffusion and mechanical dispersion. Each of them produces a solute flux per unit surface and unit time. There are as many transport equations as chemical components or primary species in the system. Mass balance equation for the $j$-th component is given by

$$
\rho_{l} X_{l}^{w} \phi S_{l} \frac{\partial C_{j}}{\partial t}+\frac{\partial\left(\rho_{l} X_{l}^{w} \phi S_{l} P_{j}\right)}{\partial t}+\frac{\partial\left(\rho_{l} X_{l}^{w} \phi S_{l} W_{j}\right)}{\partial t}+\frac{\partial\left(\rho_{l} X_{l}^{w} \phi S_{l} Y_{j}\right)}{\partial t}=L^{*}\left(C_{j}\right)+r_{i}\left(C_{j}^{0}-C_{j}\right)
$$

where $C_{j}, P_{j}, W_{j}$ and $Y_{j}$ are total dissolved, precipitated, total exchanged and total sorbed concentrations of the $\mathrm{j}$-th component, respectively, $r_{i}$ is the sink term, $\mathrm{C}_{\mathrm{j}}^{0}$ is the dissolved concentration of the $\mathrm{j}$-th species in the sink term $r_{i}$, and $\mathrm{L}^{*}(\mathrm{l})$ is the following operator:

$$
\mathrm{L}^{*}(\cdot)=\nabla \cdot\left(\rho_{l} \mathrm{X}_{1}^{\mathrm{w}} \phi S_{l} \mathbf{D}^{\mathrm{j}} \nabla(\cdot)\right)-\rho_{\mathrm{l}} \mathrm{X}_{1}^{\mathrm{w}} \mathbf{q}_{\mathrm{l}} \nabla(\cdot)+\left(\mathrm{r}_{\mathrm{e}}-\mathrm{r}_{\mathrm{c}}\right)(\cdot)
$$

where $r_{e}$ and $r_{c}$ are the evaporation and condensation rates, respectively and $\boldsymbol{D}^{j}$ is the dispersion tensor which is given by

$$
\phi S_{l} \mathbf{D}^{\mathrm{j}}=\mathbf{I} D_{e}+\phi S_{l} \mathbf{D}_{h}
$$

where $\boldsymbol{I}$ is the identity tensor, $\boldsymbol{D}_{h}$ is the mechanical dispersion tensor and $D_{e}$ is the effective diffusion coefficient which is assumed to be the same for all chemical species. 


\subsubsection{Chemical reactions}

The geochemical model includes the following reactions: aqueous complexation, acid-base, redox, mineral dissolution/precipitation, gas dissolution/ex-solution and cation exchange. The chemical system is defined in terms of the following primary species: $\mathrm{H}_{2} \mathrm{O}, \mathrm{H}^{+}, \mathrm{O}_{2}(\mathrm{aq}), \mathrm{Ca}^{2+}, \mathrm{Mg}^{2+}$, $\mathrm{Na}^{+}, \mathrm{K}^{+}, \mathrm{Cl}^{-}, \mathrm{SO}_{4}{ }^{2-}, \mathrm{HCO}_{3}{ }^{-}, \mathrm{Fe}^{2+}$ and $\mathrm{SiO}_{2}(\mathrm{aq})$. Relevant aqueous complexes were identified from speciation runs performed with EQ3/6 (Wolery, 1992). The main mineral phases controlling the chemistry of Opalinus pore water are quartz, calcite, dolomite, gypsum and ferrihydrite (Pearson et al., 2003). Dissolution/precipitation of these minerals is assumed here to proceed at local equilibrium. Dissolution of pyrite and siderite is computed by using kinetic laws (Williamson and Rimstidt, 1994; Xu et al., 2006). Mineral equilibrium and aqueous complexes constants are taken from the EQ3/6 database (Wolery, 1992). The Gaines-Thomas convention is used for cation exchange (Gaines and Thomas, 1953). Selectivity coefficients for cation exchange reactions are taken from Pearson et al. (2003). Table 2 lists equilibrium constants for aqueous complexes, minerals and gases and selectivity coefficients for cation exchange reactions.

\subsection{Numerical model}

The model assumes 2D-axial symmetry. The spatial domain is discretized with a rectangular mesh of 204 nodes and 101 finite elements (Figure 3). Values of main hydrodynamic parameters of Opalinus clay include: density of solids $=2.71 \mathrm{~kg} / \mathrm{dm}^{3}$, porosity $=0.1605$, hydraulic conductivity $=$ $2 \times 10^{-13} \mathrm{~m} / \mathrm{s}$ and vapor tortuosity $=0.8$. Relative permeability, $k_{r}$, is computed with $k_{r}=S_{l}^{4}$ where $S_{l}$ is the liquid saturation degree. Retention curve was taken from Lloret (2002):

$$
S_{l}=0.007+\left[1+\left(\frac{s}{20}\right)^{1.67}\right]^{-0.4}
$$

where $s$ is suction in $\mathrm{kPa}$. 
Longitudinal dispersivity is $0.12 \mathrm{~m}$ while the effective diffusion coefficient, $D_{e}$, is equal to $1.73 \times 10^{-11} \mathrm{~m}^{2} / \mathrm{s}$ for all chemical species.

Except for dissolved oxygen, the initial chemical composition of Opalinus clay pore water was inferred from aqueous extract data of undisturbed samples taken from radial distances greater than $0.8 \mathrm{~m}$ in boreholes BVE-97, BVE-99, BVE-100, BVE-101 and BVE-102 (Table 3). Aqueous extract data were interpreted with the inverse hydrochemical model of Zheng et al. (2008) by assuming that the initial clay pore water is in equilibrium with quartz, calcite, dolomite and pyrite. The latter phase controls the initial redox potential which is equal to $0.09 \mathrm{~V}$ and the concentration of $\mathrm{O}_{2}(\mathrm{aq})$ which is equal to $4.3 \cdot 10^{-51} \mathrm{M}$ (Table 3). The concentration of dissolved $\mathrm{Cl}^{-}$in Table 3 corresponds to the case that chloride is not affected by anion exclusion.

Initial volume fractions of minerals used in the model (Table 4) were taken from Pearson $e t$ al. (2003). The cation exchange capacity (CEC) in the Opalinus clay is $11.68 \mathrm{meq} / 100 \mathrm{~g}$, a mean value of three measured CEC presented in Pearson et al. (2003). The model assumes a constant temperature of $15^{\circ} \mathrm{C}$ and extends over all 9 phases of VE.

It is known that dissolved $\mathrm{Cl}^{-}$in clay media exhibits anion exclusion because it can only access a part of the total porosity. Standard multicomponent reactive transport models usually disregard anion exclusion because it is not straightforward to maintain electroneutrality or charge balance when anion exclusion is considered. The relevance of anion exclusion for $\mathrm{Cl}^{-}$has been analyzed by considering the following two values of accessible porosity equal to: (1) The total porosity (no anion exclusion) and (2) 54\% of total porosity (anion exclusion). Such cases were solved with two independent models. The first one considers the transport of a single conservative species with an accessible porosity equal to $54 \%$ of the total porosity. The second model is a multicomponent reactive transport model in which all species including $\mathrm{Cl}^{-}$can access all the porosity. In this case, the maximum charge balance error is $5.8 \%$.

For transient flow with variable water content, anion exclusion is assumed to vary linearly with water content, $\theta_{l}$, so that accessible water content, $\theta_{l a}$, is updated according to: 


$$
\theta_{l a}=\frac{\phi_{a}}{\phi} \theta_{l}
$$

where $\phi_{a}$ is accessible porosity and $\phi$ is total porosity. Anion exclusion is expected to become less relevant when concentrations increase due to water evaporation. However, the linear relationship in Eq. (13) is a good approximation for the VE model because computed relative humidities at the rock surface are always greater than $85 \%$ and therefore the rock does not get very dry.

\subsection{Code description}

The multiphase flow and reactive transport model of VE has been performed with INVERSE-FADES-CORE $^{2 \mathrm{D}}$ (Zheng and Samper, 2004), a code which solves both forward and inverse multiphase flow and multicomponent reactive transport problems in 1-, 2- and 3-D axialsymmetric porous and fractured media. This code integrates the capabilities of FADES (Navarro and Alonso, 2000), CORE $^{2 \mathrm{D}}$ (Samper et al., 2003a) and INVERSE-CORE ${ }^{2 \mathrm{D}}$ (Dai and Samper, 2004). State variables of forward model are temperature and liquid and gas pressures which are solved by using an iterative Newton-Raphson method. Reactive transport equations are solved with a sequential iteration method. The inverse problem is solved by minimizing a generalized leastsquares criterion with a Gauss-Newton-Levenberg-Marquardt method (Dai and Samper, 2004). Forward routines of INVERSE-FADES-CORE ${ }^{2 D}$ have been widely verified with analytical solutions and validated by applying them to the simulation of THC and THMC problems (Samper $e t$ al., 2006c; Zheng, 2006; Samper et al., 2008a). Codes of CORE ${ }^{2 \mathrm{D}}$ (Samper et al., 2003a) series have been used to model laboratory tests and field case studies (Samper et al., 2003b; Molinero et al., 2004; Dai and Samper, 2004; Molinero and Samper, 2006; Dai and Samper, 2006; Dai et al., 2006; Samper et al., 2006a,b; Zhang et al., 2008; Samper et al., 2008b), evaluate the long-term geochemical evolution of HLW repositories in clay (Yang et al., 2007) and granite (Yang et al., 2008), analyze stochastic transport and multicomponent competitive cation exchange in aquifers (Samper and Yang, 2006) and study concrete degradation (Galíndez et al., 2006). 


\section{Model results}

\subsection{Hydrodynamic model results}

The numerical solution obtained with INVERSE-FADES-CORE ${ }^{2 \mathrm{D}}$ (Dai and Samper, 2004) was compared with those of Mayor et al. (2007) computed with CODE-BRIGHT (Olivella et al., 1996). Liquid and gas pressures and temperatures computed with INVERSE-FADES-CORE ${ }^{2 D}$ are similar to those obtained with CODE-BRIGHT. There are some small differences between both models which are caused mainly by the fact that the model of Mayor et al. (2007) is 2D in a vertical plane while ours is $1 \mathrm{D}$ axy-symmetric. Initial values of the turbulence factorin Eq. 8 for phases 6 and 7 were taken from Mayor et al. (2005). Later, their values were modified during the calibration of the model (see Table 1).

For the most part, model results reproduce measured liquid pressure, rock outflow and relative humidity data (Figures 4 to 7). Discrepancies between computed and measured liquid pressures are observed during the first ventilation period (Figure 4). Computed results after December 2003 have a different trend than measured data (Figure 4). Similar to the model of Mayor et al. (2007), our model calculates a continuing drop in liquid pressure at a distance of $2 \mathrm{~m}$ after the resaturation period which started in January 2004 because this point is not close enough to the tunnel. This is not a limitation of the model because the model reproduces the effect of resaturation at a point located $0.25 \mathrm{~m}$ from the tunnel (Figure 5). Since water flow is a diffusive process, the effect of resaturation at a point located $2 \mathrm{~m}$ away from the tunnel is noticed after a few months. Discrepancies between computed and measured liquid pressures at this point (Figure 4) are most probably caused by the lack of reliability of liquid pressure measurements for pressures below 100 $\mathrm{kPa}$ (Mayor et al., 2007).

Although computed rock outflows reproduce the general trend of measured data at the end of phase 6 , model results overestimate measured data (Figure 6). Computed rock outflow is $2.66 \mathrm{~g} / \mathrm{m}^{2} \mathrm{~h}$, while measured data is $1.8 \mathrm{~g} / \mathrm{m}^{2} \mathrm{~h}$. The value computed by Mayor et al. (2007) at the end of phase 6 
is $3.41 \mathrm{~g} / \mathrm{m}^{2} \mathrm{~h}$. Computed relative humidity near the rock surface overestimates significantly measured data (Figure 7). Computed relative humidity at the tunnel surface at the end of phase 6 is almost $85 \%$, while the mean value from hygrometer measurements is $62.5 \%$. The computed value of Mayor et al. (2007) at the end of phase 6 is equal to $83 \%$. Overestimation of relative humidities could be related to uncertainties in the turbulence factor. However, computed relative humidities reproduce the trend of measured data at a radial distance of $0.25 \mathrm{~m}$ (Figure 5).

\subsection{Testing computed concentrations with inferred data}

Chemical data obtained from aqueous extract tests (AET) for the Opalinus clay samples at different depths from boreholes BVE-97, BVE-99, BVE-100, BVE-101 and BVE-102 are not representative of rock pore water composition. The chemical composition of clay pore water changes significantly during aqueous extraction due to dilution and chemical reactions which take place during extraction such as dissolution of soluble minerals (halite, sulphates and carbonates mostly), dissolution and ex-solution of gases, cation exchange and surface complexation. All these reactions cause nonlinear changes in concentrations of dissolved species. This makes difficult to derive the chemical composition of the original (before aqueous extraction) clay pore water from AET data (Bradbury and Baeyens, 1998; Sacchi et al. 2001; Zheng et al., 2008). Measured AET data must be re-interpreted to infer the pore water chemical composition of the clay samples. The inverse hydrochemical model of Zheng et al. (2008) was used to infer the chemical composition of 41 samples at different depths in boreholes BVE-97, BVE-99 and BVE-100.

The effect of in situ oxidation and evaporation on sulphate concentration was modelled by relating the changes in the partial pressure of oxygen, $P_{O 2}$, to changes in liquid saturation, $S_{l}$. For liquid saturation degrees below $90 \%, P_{O 2}$ is assumed to be equal to the atmospheric oxygen pressure. The following linear expression is used to relate $\log P_{O 2}$ to $S_{l}$ when $90<S_{l}<100$ : 


$$
\frac{\log \left(P_{O 2}\right)}{\log \left(P_{\text {O2atm }}\right)}=a\left(1-S_{l}\right) \times 100-b
$$

where $a$ and $b$ are parameters which initially are equal to 2 and -20 , respectively and later are adjusted during model calibration. The model assumes that the system is open to $\mathrm{CO}_{2}$ in the desaturated zone where the partial pressure is fixed equal to $10^{-3.5}$ bar and the supply of $\mathrm{CO}_{2}$ is assumed infinite.

Chloride may suffer anion exclusion. Two values of accessible porosity were considered: (1) 0.160 (no anion exclusion) and (2) 0.086 (anion exclusion). The time evolution of dissolved chloride in the rock at a depth of $2 \mathrm{~cm}$ shows the effects of desaturation (Figure 8). During the background history, natural evaporation caused a slight increase in chloride concentration. After that, desaturation by ventilation induced significant evaporation of pore water and consequently chloride concentration increased dramatically. During the resaturation phase, chloride concentrations decreased due to dilution. Model results overestimate inferred chloride data after desaturation (phase 6) at a point in the rock located $2 \mathrm{~cm}$ from the tunnel surface (Figure 8). However, computed chloride concentrations at the end of the desaturation phase 6 match inferred data (Figure 9). Model results also reproduce inferred data after resaturation in phase 8 (Figure 10). The spatial distribution of measured and computed concentrations of dissolved $\mathrm{Cl}^{-}$at the end phases 6 (Figure 9) and 8 (Figure 10) for the two values of accessible porosity corresponding to anion exclusion and no anion exclusion show that the model with anion exclusion fits measured data slightly better than the model without anion exclusion.

The radial distribution of cumulative pyrite dissolution/precipitation at the end of phases 3,6 and 8 shows that pyrite was oxidized throughout phases 6 to 8 due to in-diffusion of oxygen. Oxidation takes place also during the resaturation phase 8 (Figure 11). Oxidation of pyrite leads to the increase of concentrations of dissolved sulphate, $\mathrm{Fe}^{2+}$ and protons according to:

$$
\mathrm{FeS}_{2}(\mathrm{~s})+\mathrm{H}_{2} \mathrm{O}+3.5 \mathrm{O}_{2}(\mathrm{aq}) \Leftrightarrow 2 \mathrm{SO}_{4}{ }^{2-}+\mathrm{Fe}^{2+}+2 \mathrm{H}^{+}
$$


The intruded oxygen oxidizes $\mathrm{Fe}^{2+}$ and causes siderite dissolution according to (Figure 12):

$$
\mathrm{FeCO}_{3}(\mathrm{~s})+\mathrm{H}^{+} \Leftrightarrow \mathrm{Fe}^{2+}+\mathrm{HCO}_{3}^{-}
$$

Siderite and pyrite compete for the consumption of oxygen. Their dissolution rates depend on their kinetic rates and specific surface areas. The kinetic rate for siderite, $R_{\text {sid }}$, was taken from $\mathrm{Xu}$ et al. (2006) and is given by:

$$
R_{\text {sid }}=\left(1.3 \times 10^{-11}+6.58 \times 10^{-9} a_{H}^{0.5}\right) \cdot(1-\Omega)
$$

where $\Omega$ is the saturation index of siderite and $a_{H}$ is the activity of protons. The kinetic rate of pyrite dissolution, $R_{p y r}$, was derived from Williamson and Rimstidt (1994):

$$
R_{p y r}=\left(6.5 \times 10^{-11} a_{O 2}^{0.5} a_{H}^{-0.11}+8.5 \times 10^{-9} a_{F e^{3+}}^{0.93} a_{F e^{2+}}^{-0.4}\right) \cdot(1-\Omega)
$$

where $a_{\mathrm{O}_{2}}, a_{\mathrm{Fe}^{3+}}$ and $a_{\mathrm{Fe}^{2+}}$ are aqueous activities of dissolved oxygen, $\mathrm{Fe}^{3+}$ and $\mathrm{Fe}^{2+}$, respectively. The specific area of siderite was taken equal to $0.095 \mathrm{~m}^{2} / \mathrm{g}(\mathrm{Xu}$, et al., 2006) while that of pyrite was $0.16 \mathrm{~m}^{2} / \mathrm{g}$, slightly larger than the value reported by Williamson and Rimstidt (1994). The dissolution of pyrite and siderite induces the precipitation of $\mathrm{Fe}(\mathrm{OH})_{3}(\mathrm{~s})$ (Figure 13) according to:

$$
2.5 \mathrm{H}_{2} \mathrm{O}+0.25 \mathrm{O}_{2}(\mathrm{aq})+\mathrm{Fe}^{2+} \Leftrightarrow \mathrm{Fe}(\mathrm{OH})_{3}(\mathrm{~s})+2 \mathrm{H}^{+}
$$

The dissolution of about $0.0006 \mathrm{~mol} / \mathrm{L}$ of pyrite and $0.0008 \mathrm{~mol} / \mathrm{L}$ of siderite lead to the precipitation of $0.0014 \mathrm{~mol} / \mathrm{L}$ of $\mathrm{Fe}(\mathrm{OH})_{3}(\mathrm{~s})$ at the end of the second ventilation period (phase 8). Dissolution of calcite (Figure 14) buffers $\mathrm{pH}$ according to:

$$
\mathrm{CaCO}_{3}(\mathrm{~s})+\mathrm{H}^{+} \Leftrightarrow \mathrm{Ca}^{2+}+\mathrm{HCO}_{3}^{-}
$$

Dissolved $\mathrm{Ca}^{2+}$ and $\mathrm{HCO}_{3}{ }^{-}$released by calcite induce gypsum and dolomite precipitation in accordance with (Figures 15 and 16): 


$$
\begin{aligned}
& \mathrm{Ca}^{2+}+\mathrm{SO}_{4}{ }^{2-}+2 \mathrm{H}_{2} \mathrm{O} \Leftrightarrow \mathrm{CaSO}_{4}(\mathrm{~s}) \cdot 2 \mathrm{H}_{2} \mathrm{O} \\
& \mathrm{Mg}^{2+}+\mathrm{Ca}^{2+}+2 \mathrm{HCO}_{3}{ }^{-} \Leftrightarrow \mathrm{CaMg}\left(\mathrm{CO}_{3}\right)_{2}(\mathrm{~s})+2 \mathrm{H}^{+}
\end{aligned}
$$

Dissolution of $\mathrm{CO}_{2}$ gas and siderite provides sources of carbonate which favor dolomite precipitation. The main processes controlling the chemical evolution of reactive species are: evaporation induced by desaturation, dilution caused by resaturation and chemical reactions. Pyrite oxidation (Figure 11) leads to large concentrations of dissolved $\mathrm{SO}_{4}{ }^{2-}$ near the rock surface (Figure 17) although resaturation and gypsum precipitation (Figure 15) tend to decrease $\mathrm{SO}_{4}{ }^{2-}$ concentration. Precipitation of gypsum (Figure 15) and dolomite (Figure 16) mitigate the effect of calcite dissolution (Figure 14). As a result, only moderately elevated $\mathrm{Ca}^{2+}$ concentrations are observed (Figure 18). Dissolved $\mathrm{HCO}_{3}^{-}$and $\mathrm{Mg}^{2+}$ concentrations exhibit a similar behavior to that of dissolved $\mathrm{Ca}^{2+}$. Although dissolved $\mathrm{Na}^{+}$is affected by cation exchange and dilution in the resaturation phase, it shows large concentrations near the rock surface (Figure 19). $\mathrm{K}^{+}$dissolved concentration behaves in a manner similar to $\mathrm{Na}^{+} . \mathrm{pH}$ remains nearly constant along radial distance because it is buffered by calcite (Figure 20).

Mineral dissolution/precipitation in the unsaturated zone changes rock porosity. Mineral dissolution/precipitation causes a net decrease of porosity (Figure 21). Porosity changes are generally smaller than $1 \%$, although the maximum reaches $5 \%$ near the rock surface.

Based on Odong (2007) who found that the Kozeny-Carman equation is the best estimator of hydraulic conductivity from grain-size data for a wide range of soil types, changes in porosity, $\phi$, in the VE were related to changes in permeability, $K$, by

$$
K=K_{0} \frac{\phi^{3}}{(1-\phi)^{2}} \frac{\left(1-\phi_{0}\right)^{2}}{\phi_{0}^{3}}
$$


where $K_{0}$ and $\phi_{0}$ are reference values of permeability and porosity, respectively, and $K$ is the permeability for a given porosity $\phi$. Permeability changes in Opalinus clay caused by ventilation are smaller than $2 \%$.

The evaporation from the surface of the tunnel induces a desaturated zone where both $\mathrm{O}_{2}$ and $\mathrm{CO}_{2}$ can enter. Dissolution of $\mathrm{CO}_{2}$ in the porewater provides sufficient carbonate for dolomite to precipitate. X-Ray diffraction analyses on samples from VE cores taken after resaturation phase 8 (Fernández et al., 2006) indicate that dolomite is present in samples taken at depths between 0.1 and $1 \mathrm{~m}$. The main geochemical processes taking place at the desaturated zone are controlled by the dynamic balance between siderite, pyrite and $\mathrm{Fe}(\mathrm{OH})_{3}$, which is characterized by the dissolution of siderite and pyrite and the precipitation of $\mathrm{Fe}(\mathrm{OH})_{3}$. The amounts of dissolution/precipitation of these minerals depend on model assumption (equilibrium versus kinetics) and kinetic parameters such as surface areas and kinetic rate laws. The extreme assumption of chemical equilibrium for siderite and $\mathrm{Fe}(\mathrm{OH})_{3}$ leads to a large siderite dissolution and a small pyrite dissolution. Siderite consumes all the oxygen in the model, leaving little for pyrite. If both dissolution of pyrite and siderite are assumed to be kinetically controlled, then the amounts of siderite dissolution and $\mathrm{Fe}(\mathrm{OH})_{3}$ precipitation are smaller than those corresponding to the case of siderite at local equilibrium. The fact that mineralogical analyses from VE cores taken after resaturation do not show massive precipitation of $\mathrm{Fe}(\mathrm{OH})_{3}$ tend to support the hypothesis of kinetic siderite dissolution.

\section{Model uncertainties}

Main uncertainties of the multiphase flow model include: 1) Values of the turbulence factor in Eq. 8 to calculate the vapor flux into the tunnel, 2) Anisotropy in rock permeability and molecular diffusion, 3) Lack of uniform conditions along the tunnel, and 4) Local rock heterogeneities. The most important sources of uncertainty of reactive transport model are: 1) Hydrochemical data from 
VE which may be affected by excessive oxidation during storage, and 2) The geochemical model which could be improved by accounting for proton surface complexation.

Some of these uncertainties have been evaluated by sensitivity analyses. Sensitivity runs of rock outflow to changes in turbulence factor were performed. Figure 22 illustrates the sensitivity of rock outflow to changes in the turbulence factor of phases 6 and 7. Results are compared for the turbulence factors of Mayor et al. (2005) and those calibrated with the model presented here (see Table 1). Clearly, the lower the turbulence factor the lower the rock outflow in phase 6 . Sensitivity analyses were performed also for dispersivity and molecular diffusion coefficient. Model results are sensitive to changes in dispersivity around its calibrated value of $0.12 \mathrm{~m}$ (Figure 23). Concentrations are sensitive to a decrease in the diffusion coefficient but not to an increase of such parameter (Figure 24).

Current multiphase flow and multicomponent reactive transport models disregard anion exclusion for $\mathrm{Cl}^{-}$because they cannot guaranty charge balance. Dual continuum models such as that of Samper et al. (2008b) or that reported by Appelo and Werzin (2007) for tritium, iodide and sodium in Opalinus clay offer a possibility to account for anion exclusion and enhanced cation effective diffusion.

Preserving in situ conditions of core samples before aqueous extraction is not straightforward. As indicated by Sacchi and Michelot (2000), Sacchi et al. (2001) and Pearson et al. (2003), oxidation of pyrite may take place on OPA clay cores during core sampling, storage, sample preparation for the aqueous extract tests, and aqueous extraction. The acidity generated by pyrite oxidation results in the dissolution of calcite. The released dissolved $\mathrm{Ca}^{2+}$ displaces dissolved $\mathrm{Na}^{+}$ from exchange sites. The initial chemical composition of OPA pore water at VE in Table 3 was obtained from an inverse interpretation of measured aqueous extract data taken from radial distances greater than $0.8 \mathrm{~m}$ (not affected by desaturation). This model considers the oxidation of pyrite during the aqueous extraction, but not the oxidation during sampling, storage and preparation. The initial concentration of dissolved $\mathrm{SO}_{4}{ }^{2-}$ in Table 3 is an order of magnitude larger than common 
concentrations of $\mathrm{SO}_{4}{ }^{2-}$ in Opalinus clay in Mont Terri (Pearson et al., 2003). In a similar manner, the $\mathrm{Na} / \mathrm{Cl}$ ratio in Table 3 is greater than 1 while it is normally less than 1 in Mont Terri pore waters. Oxidation of pyrite in OPA clay cores from VE during core sampling, storage, sample preparation may be responsible for the discrepancies between initial concentrations for VE in Table 3 and those typically found in Opalinus clay at other locations of Mont Terri laboratory. Concentrations in Table 3 may not be representative of initial in situ conditions at VE. Future studies should rely on hydrochemical data from cores not affected by pyrite oxidation.

\section{Conclusions}

A multiphase flow and reactive transport model of the ventilation experiment performed on Opalinus clay has been presented. The model reproduces measured vapor flux, liquid pressure and inferred chemical data. Model results reproduce also the trend of measured relative humidity, although such data are slightly overestimated near the rock interface after the desaturation phase due to uncertainties in the turbulence factor. Model results show that anion exclusion may be relevant for chloride.

The main processes controlling the evolution of reactive species include: 1) Condensation by desaturation, 2) Dilution by resaturation, 3) Dispersion and diffusion, and 4) Chemical reactions such as pyrite oxidation which leads to dissolution of calcite and siderite, precipitation of ferrihydrite, dolomite and gypsum and cation exchange. $\mathrm{pH}$ in the unsaturated rock varies from 7.8 to 8 and is mostly buffered by calcite.

Model results allow one to conclude that changes in porosity of Opalinus clay in the unsaturated zone caused by oxidation and mineral dissolution/precipitation are smaller than $5 \%$. Therefore, ventilation of underground drifts during construction and operational phases of a HLW repository in clay is not expected to affect significantly rock properties. 


\section{Acknowledgements}

This work has been funded by ENRESA and University of La Coruña through a research scholarship awarded to the first author. It also partially funded through Contract No. DE-AC0205CH11231 with the U.S. Department of Energy. We thank all the support provided by M. Velasco from Dames \& Moore Iberia. We also thank the two anonymous reviewers for their extremely good and pertinent comments, suggestions and recommendations which have contributed to significantly improve the paper.

\section{References}

Appelo C.A.J and P Wesin, 2007, Multicomponent Diffusion Modeling in Clay Systems with Application to the Diffusion of Tritium, Iodide, and Sodium in Opalinus Clay, Environ. Sci. Technol. 41, 5002-5007.

Bradbury, M.H., Baeyens, B., 1998. A physicochemical characterisation and geochemical modelling approach for determining pore water chemistries in argillaceous rocks. Geochimica et Cosmochimica Acta 62, 783-795.

Dai Z., Samper, J., 2004. Inverse problem of multicomponent reactive chemical transport in porous media: Formulation and Applications. Water Resources Research, Vol. 40, W07407, doi:10.1029/2004WR003248.

Dai, Z., Samper, J., 2006. Inverse modeling of water flow and multicomponent reactive transport in coastal aquifer systems. J Hydrol, 327(3-4), 447-461.

Dai Z., J. Samper and R. Ritzi, 2006, Identifying geochemical processes by inverse modeling of multicomponent reactive transport in Aquia aquifer, Geosphere, Vol. 4, No 4, 210-219.

Fernández. A.M., Melón, A., Turrero, M.J., Villar, M.V., 2006. Geochemical characterisation of the rock samples for the VE-test before a second cycle of drying. Ventilation Test Phase II. NFPRO Deliverable D4.3.5. 
Fernández-García, D., Gómez-Hernández, J.J., Mayor, J.-C., 2007. Estimating hydraulic conductivity of the Opalinus clay at a regional scale: Combined effect of desaturation and EDZ. Physics and Chemistry of the Earth 32, 639-645.

Gaines, G.I., Thomas, H.C., 1953. Adsorption studies on clay minerals. II. A formulation of the thermodynamics of exchange adsorption. J. Chem. Phys. 21, 714-718.

Galíndez, J.M., J. Molinero, J. Samper and C.B. Yang, 2006, Simulating concrete degradation processes by reactive transport models, J. Phys. IV France, Vol. 136, 177-188.

Lloret, A, 2002, Final laboratory test results report, Ventilation Experiment Internal Deliverable D4, EC Project FIS5-2001-00015.

Mayer, G., Klubertanz, G., Croisé, J., 2007. Modelling of the in situ ventilation experiment in the Opalinus clay. Physics and Chemistry of the Earth 32, 629-638.

Mayor, J.C., García-Siñeriz, J.L., Velasco, M., Gómez-Hernández, J., Lloret, A., Matray, J.-M., Coste, F., Giraud, A., Rothfuchs, T., Marschall, P., Rösli, U., Mayer, G., 2005. Ventilation experiment in Opalinus Clay for the management of radioactive waste (EURATOM Programme 1998-2002). Enresa Technical Report 07/2005. Madrid, Spain.

Mayor, J.-C., Velasco, M., García-Siñeriz, J.L., 2007. Ventilation experiment in the Mont Terri underground laboratory. Physics and Chemistry of the Earth 32, 616-628.

McDonald, M., Harbaugh, A., 1984. A modular three-dimensional finite difference ground-water flow model. US Geological Survey, Open-file Report, 83-875.

Molinero, J., Samper, J., 2006. Modeling of reactive solute transport in fracture zones of granitic bedrocks, J Cont Hydrol 82, 293-318.

Molinero, J., Samper, J., Zhang, G., Yang, C., 2004. Biogeochemical reactive transport model of the redox zone experiment of the Äspö hard rock laboratory in Sweden. Nucl Technol 148, 151165. 
Navarro, V., Alonso, E.E., 2000. Modelling swelling soils for disposal barriers. Computers and Geotechnics 27, 19-43.

Odong, J., 2007. Evaluation of Empirical Formulae for Determination of Hydraulic Conductivity based on Grain-Size Analysis, The Journal of American Science. 2007;3(3):54-60.

Olivella, S., Gens, A., Carrera, J., Alonso, E.E., 1996. Numerical formulation for a simulator (CODE_BRIGHT) for the coupled analysis of saline media. Engineering Computations 13, 87-112.

Pearson, F.J., Arcos, D., Bath, A., Boisson, J.-Y., Fernández, A.M., Gäbler, H.-E., Gaucher, E., Gautschi, A., Griffault, L., Hernán, P. and Waber, H.N., 2003. Geochemistry of water in the Opalinus Clay Formation at the Mont Terri Rock Laboratory. Swiss Federal Office for Water and Geology Series No 5, 319 pp.

Pruess, K., Oldenburg, C., Moridis, G., 1999. TOUGH2 Users guide, Version 2.0. Earth Sciences Division, Lawrence Berkeley National Laboratory, University of California, Berkeley, California, USA.

Sacchi, E., Michelot, J.L., Pitsch, H., Lalieux, P., Aranyossy, J.F., 2001. Extraction of water and solutes from argillaceous rocks for geochemical characterization: Methods, processes, and current understanding. Hydrogeology Journal 9, 17-33.

Samper J., Yang, C., 2006. Stochastic analysis of transport and multicomponent competitive monovalent cation exchange in aquifers. Geosphere 2, 102-112.

Samper, J., Yang, C., Montenegro, L., 2003a. CORE ${ }^{2 \mathrm{D}}$ version 4: A code for non-isothermal water flow and reactive solute transport. Users Manual. University of La Coruña, Spain.

Samper, J., Molinero, J., Yang, C., Zhang, G., 2003b. Redox Zone II: Coupled modeling of groundwater flow, solute transport, chemical reactions and microbial processes in the Äspö Island. SKB TR-03-16. 
Samper, J., Zhang, G., Montenegro, L., 2006a. Coupled microbial and geochemical reactive transport models in porous media: Formulation and application to synthetic and in situ experiments. J Iberian Geology 32 (2), 215-231.

Samper, J., Dai, Z., Molinero, J., Garcia-Gutierrez, M., Missana, T., Mingarro, M., 2006b. Inverse modeling of tracer experiments in FEBEX compacted Ca-bentonite. Physics and Chemistry of the Earth, Parts A/B/C, 31(10-14), 640-648.

Samper, J., Zheng, L., Montenegro, L., 2006c. Coupled THMC model for the FEBEX in situ test. In: $\mathrm{Xu}$, W. (Ed.), Proceedings of the GEOPROC 2006 International Symposium. Advances on Coupled Thermo-Hydro-Mechanical-Chemical Processes in Geosystems and Engineering, HoHai University, Nanjing, China, 97-107.

Samper, J., Zheng, L., Montenegro, L., Fernández, A.M., Rivas, P., 2008a. Coupled thermo-hydrochemical models of compacted bentonite after FEBEX in situ test. Applied Geochemistry 23/5: 1186-1201.

Samper, J., L. Zheng, A.M. Fernández and L. Montenegro, 2008b, Inverse modeling of multicomponent reactive transport through single and dual porosity media, J Cont Hydrol, Vol 98/3-4 pp 115-127.

Traber, D., 2004. Geochemical characterisation of core samples for borehole BVE-85 and BVE-86 (post desaturation phase)-geochemial process evaluation. Project Deliverable D5c\&d/D22. Rock Water Interaction Group, Institute of Geological Sciences, University of Berne, Switzerland.

Velasco, M., Pedraza, L., 2002. Ventilation experiment scoping calculation. Project Deliverable 2a. EC contract FIKW-CT 2001-00126.

Velasco, M., Pedraza, L., 2004. Hydromechanical interpretation and modelling. Project Deliverable 19a. EC contract FIKW-CT 2001-00126. 
Ward Wilson G., DG Fredlund and SL Barbour, 1994, Coupled soli-atmosphere modelling for soil evaporation, Can. Geotech J Vol 31:151-161.

Williamson, M.A., Rimstidt, J.D., 1994. The kinetics and electrochemical rate-determining step of aqueous pyrite oxidation. Geochimica et Cosmochimica Acta 58(24), 5443-5454.

Wolery, T.J., 1992. EQ3/6. A software Package for Geochemical modelling of Aqueous Systems: Package Overview and Installation Guide Version 7.0. UCRL-MA-110662-PT-I, Lawrance Livermore National Laboratory, Livermore, California, USA.

Xu, T., Sonnenthal, E., Spycher, N., Pruess, K., 2006. TOUGHREACT: A Simulation Program for Non-isothermal Multiphase Reactive Geochemical Transport in Variably Saturated Geologic Media. Computers and Geosciences 32, 145-165.

Yang, C., Samper, J., Molinero, J.,Bonilla, M., 2007. Modelling geochemical and microbial consumption of dissolved oxygen after backfilling a high level radioactive waste repository. $\mathrm{J}$ Cont Hydrol, 93, 130-148.

Yang, C., Samper, J.,Montenegro, L., 2008. A coupled non-isothermal reactive transport model for long-term geochemical evolution of a HLW repository in clay. Environmental Geology 53, 1627-1638.

Zhang, G., Samper, J., Montenegro L., 2008. Coupled thermo-hydro-bio-geochemical reactive transport model of the CERBERUS heating and radiation experiment in Boom clay. Applied Geochemistry 23, 932-949.

Zheng, L., 2006. Coupled thermo-hydro-mechanical-geochemical models for structured deformable porous media. Ph.D. Dissertation, University of La Coruña, Spain.

Zheng, L., Samper, J., 2004. Formulation of the inverse problem of non-isothermal multiphase flow and reactive transport in porous media. In: Computer Methods in Water Resources, 1317-1327. 
Zheng, L., Samper, J., Montenegro, L., 2008. Inverse hydrochemical models of aqueous extracts tests. Physics and Chemistry of the Earth (accepted) 


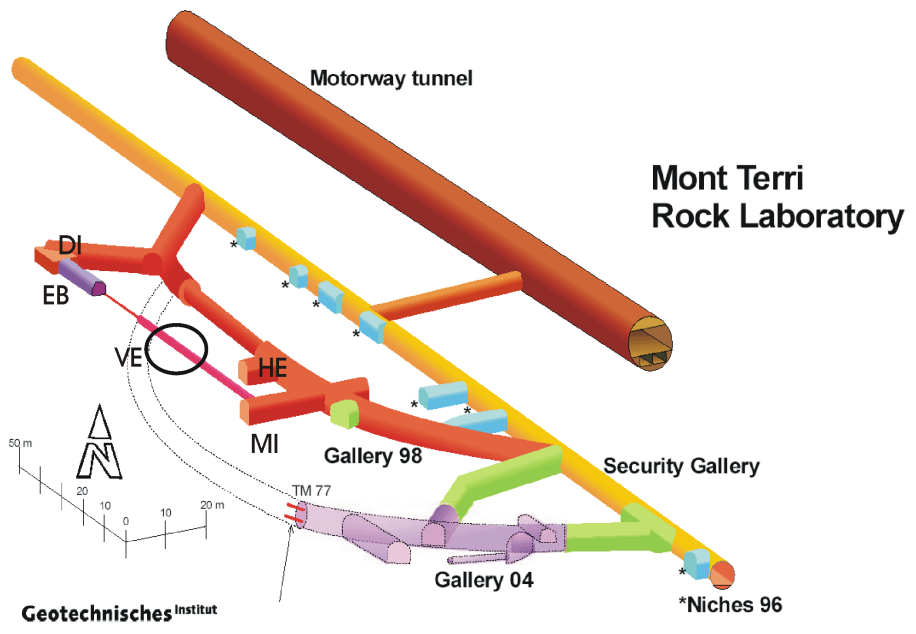

Fig. 1. Layout of Mont Terri underground research laboratory and location of the Ventilation Experiment, VE (Fernández et al. 2006).

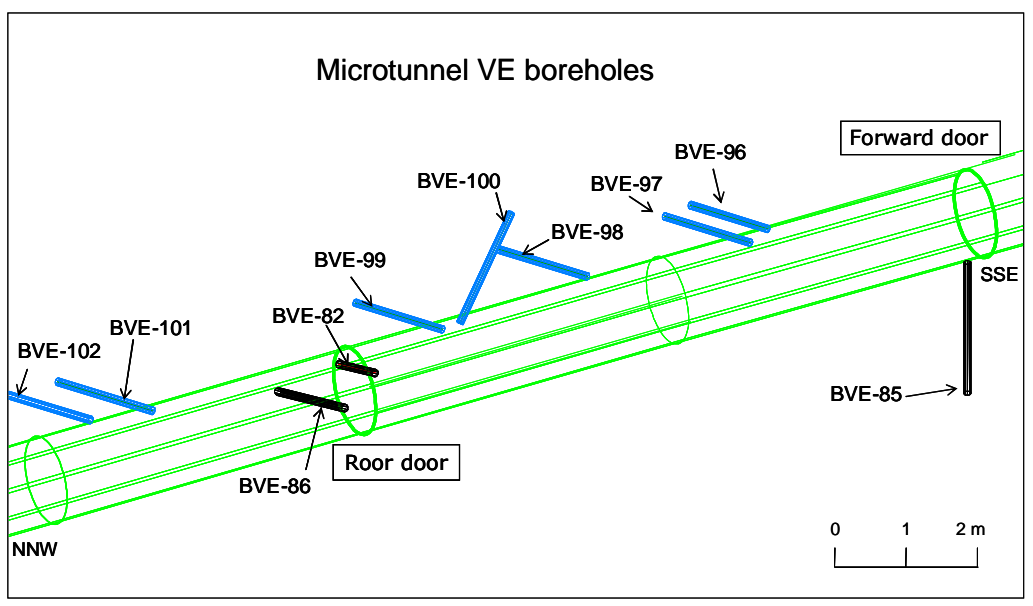

Fig. 2. Location of boreholes drilled for the geochemical characterization of ventilation experiment (modified from Fernández et al. 2006). 


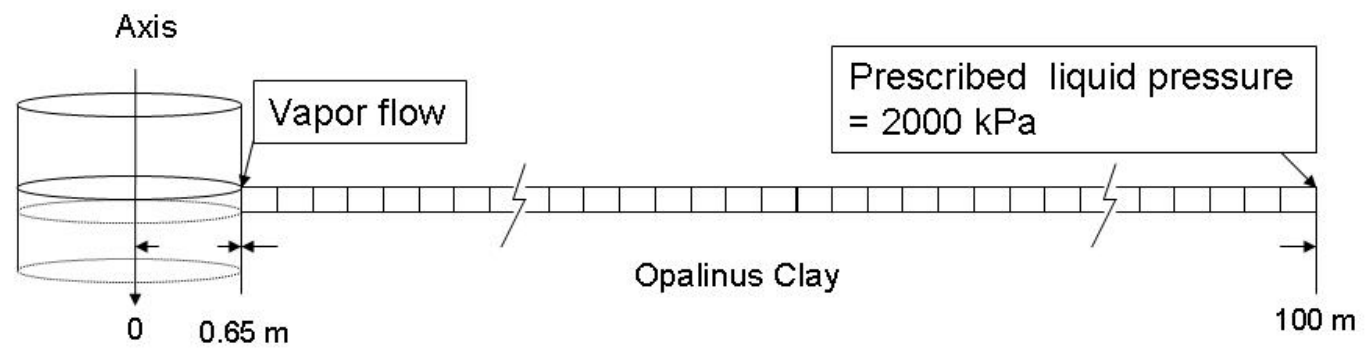

Microtunnel

Fig. 3. 2D-rectangular finite element mesh used in the numerical model of VE.

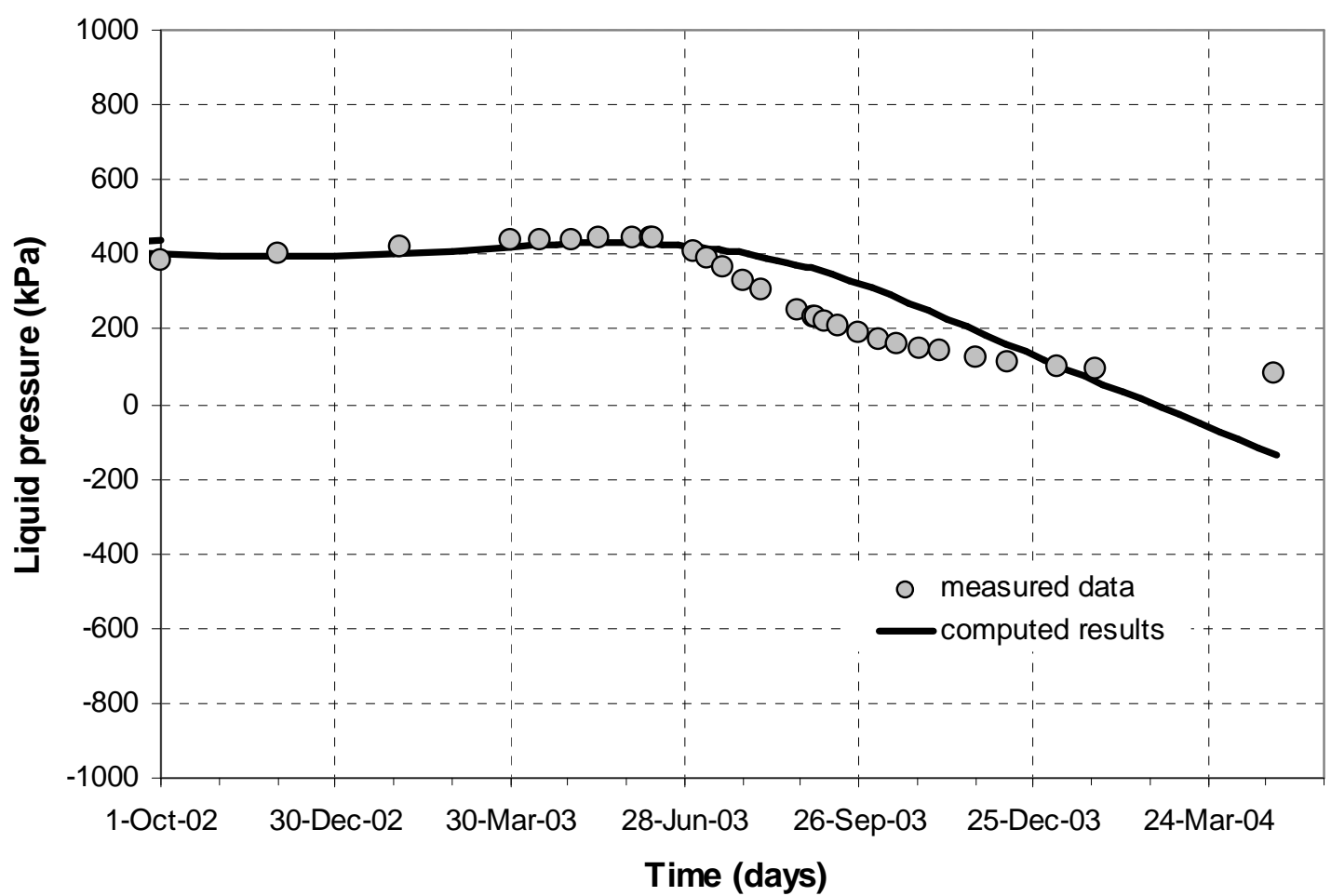

Fig. 4. Time evolution of liquid pressure at a radial distance of $2 \mathrm{~m}$. 


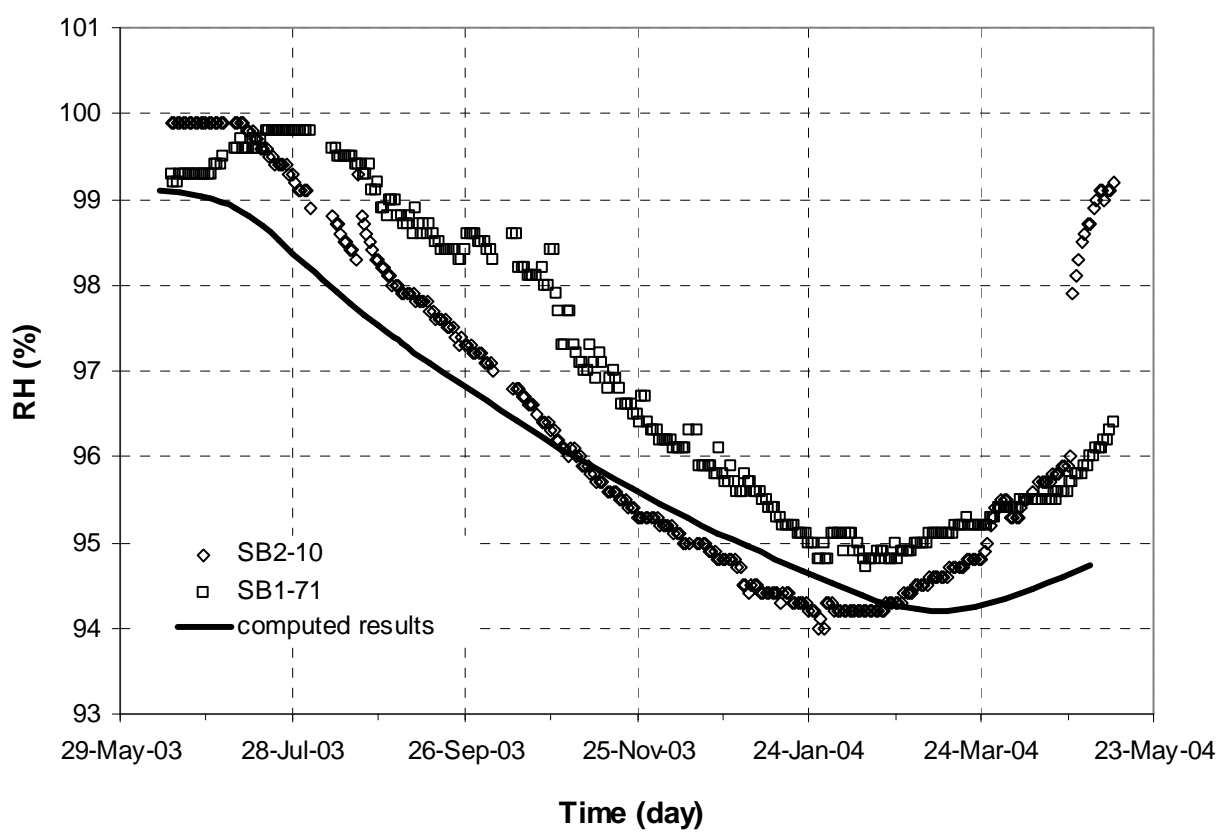

Fig. 5. Time evolution of relative humidity at $0.25 \mathrm{~m}$ of depth in the rock.

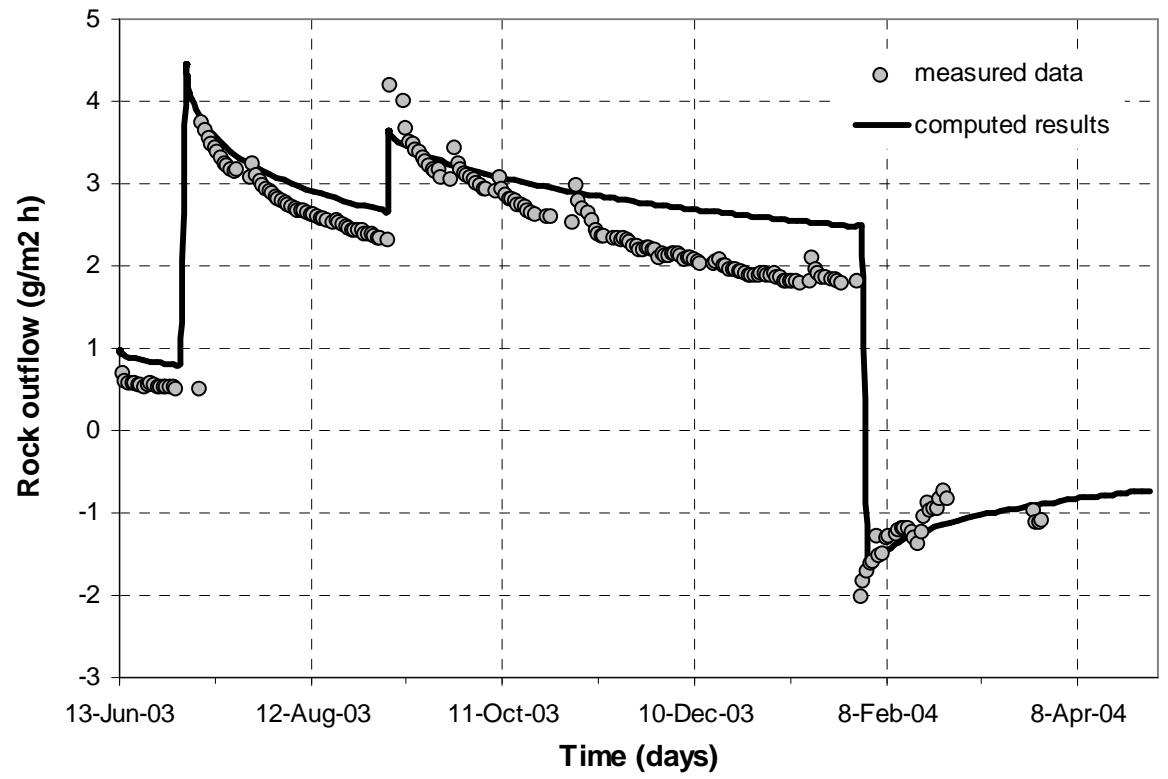

Fig. 6. Time evolution of average rock outflow. 


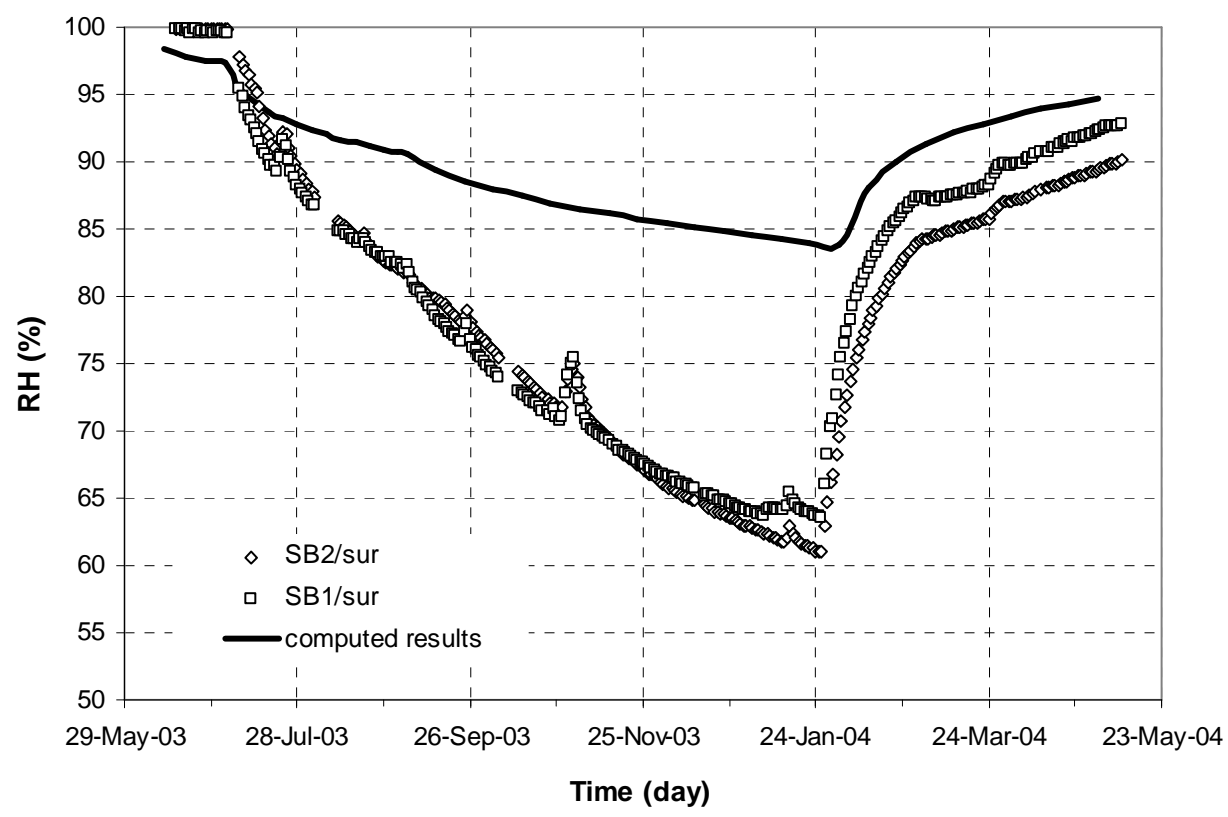

Fig. 7. Time evolution of relative humidity at the rock surface.

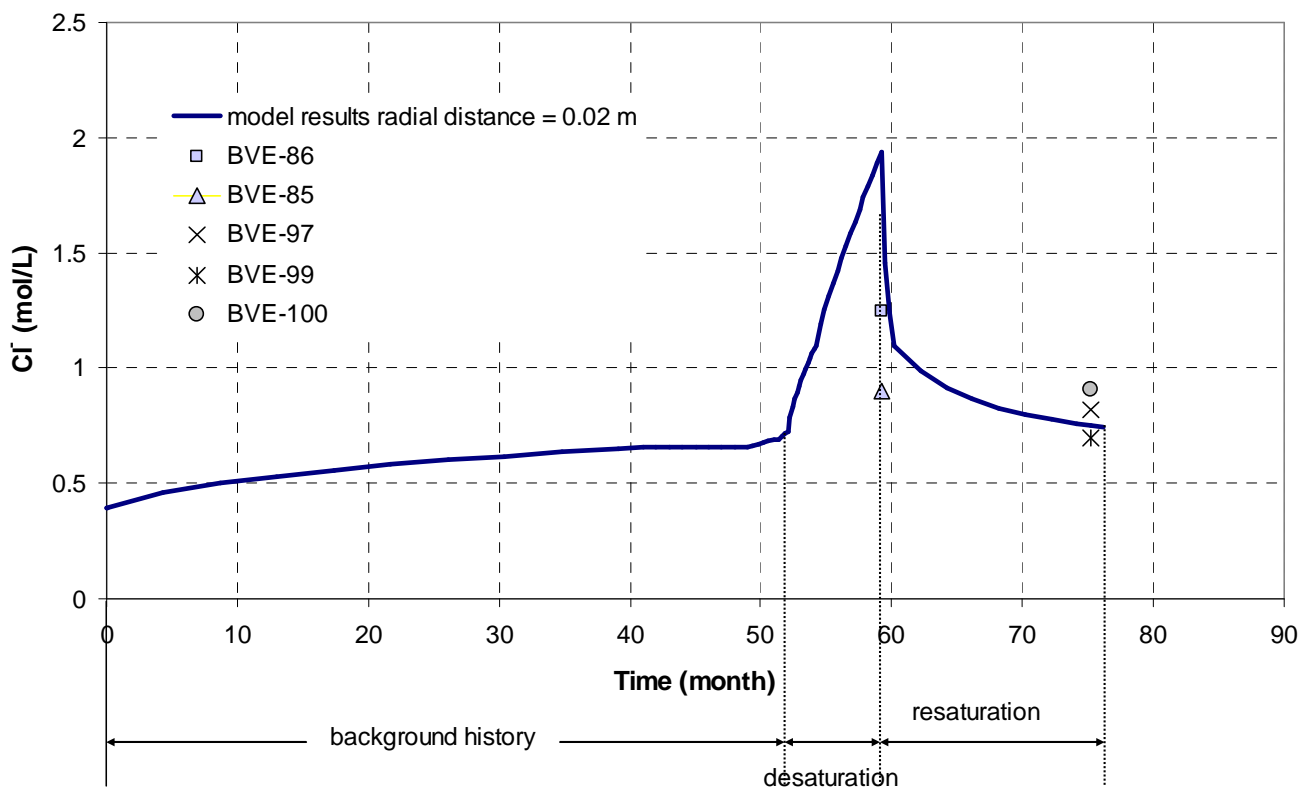

Fig. 8. Time evolution of dissolved $\mathrm{Cl}^{-}$concentration at a radial distance of $0.02 \mathrm{~m}$, assuming anion exclusion. 


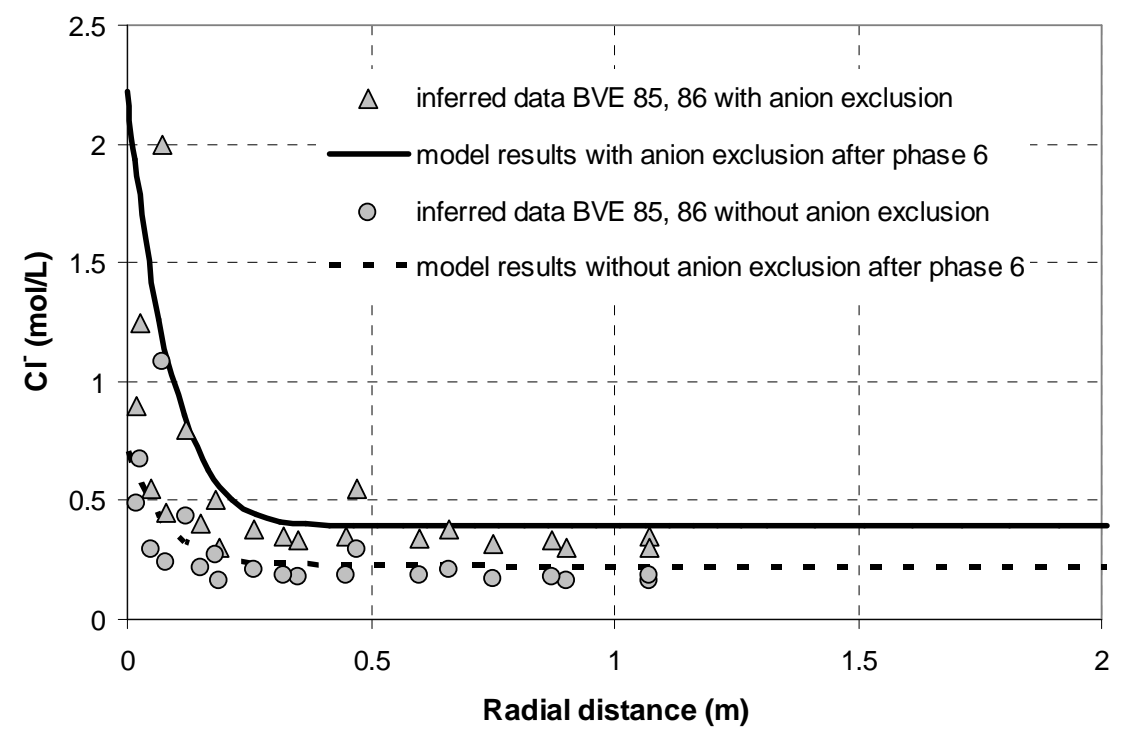

Fig. 9. Spatial distribution of measured (symbols) and computed (line) concentrations of dissolved

$\mathrm{Cl}^{-}$at the end of the first ventilation period (phase 6) for two values of accessible porosity: 0.160 (no anion exclusion) and 0.086 (with exclusion).

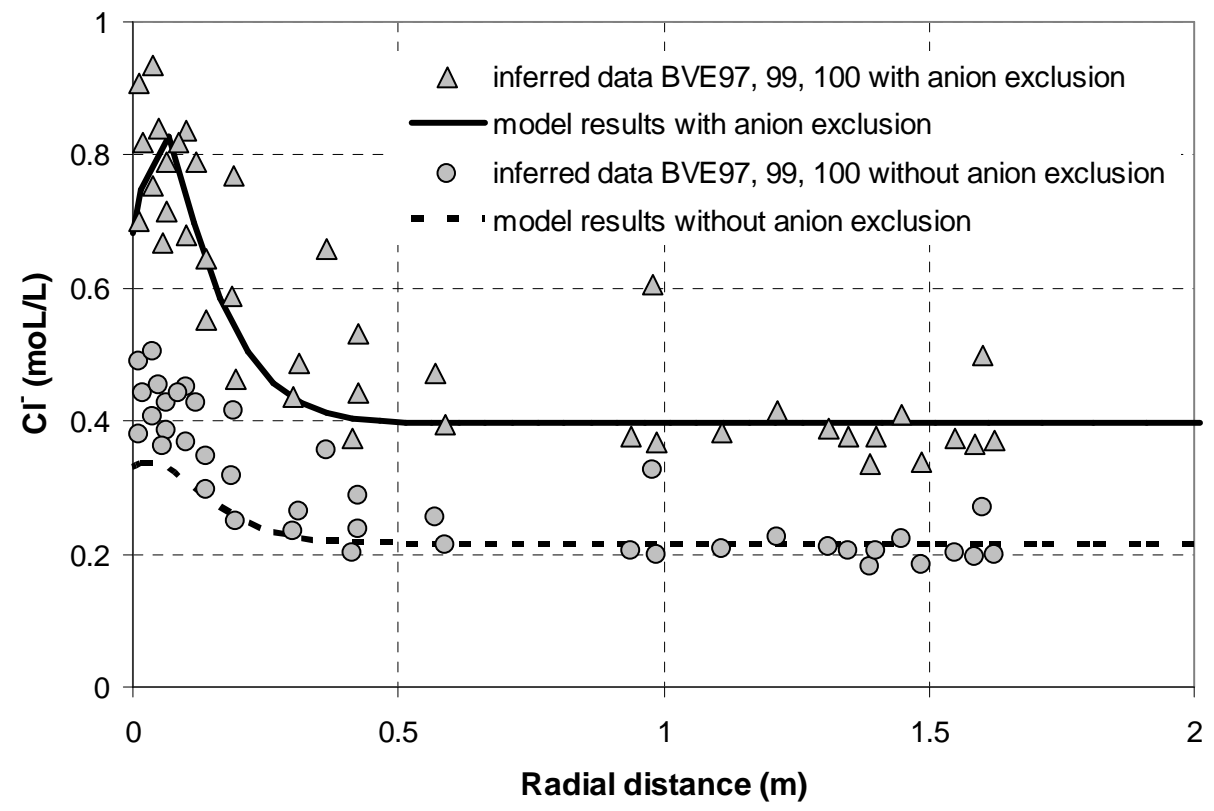

Fig. 10. Spatial distribution of measured (symbols) and computed (line) concentrations of dissolved $\mathrm{Cl}^{-}$at the end of the resaturation period (phase 8) for two values of accessible porosity: 0.160 (no anion exclusion) and 0.086 (with exclusion). 


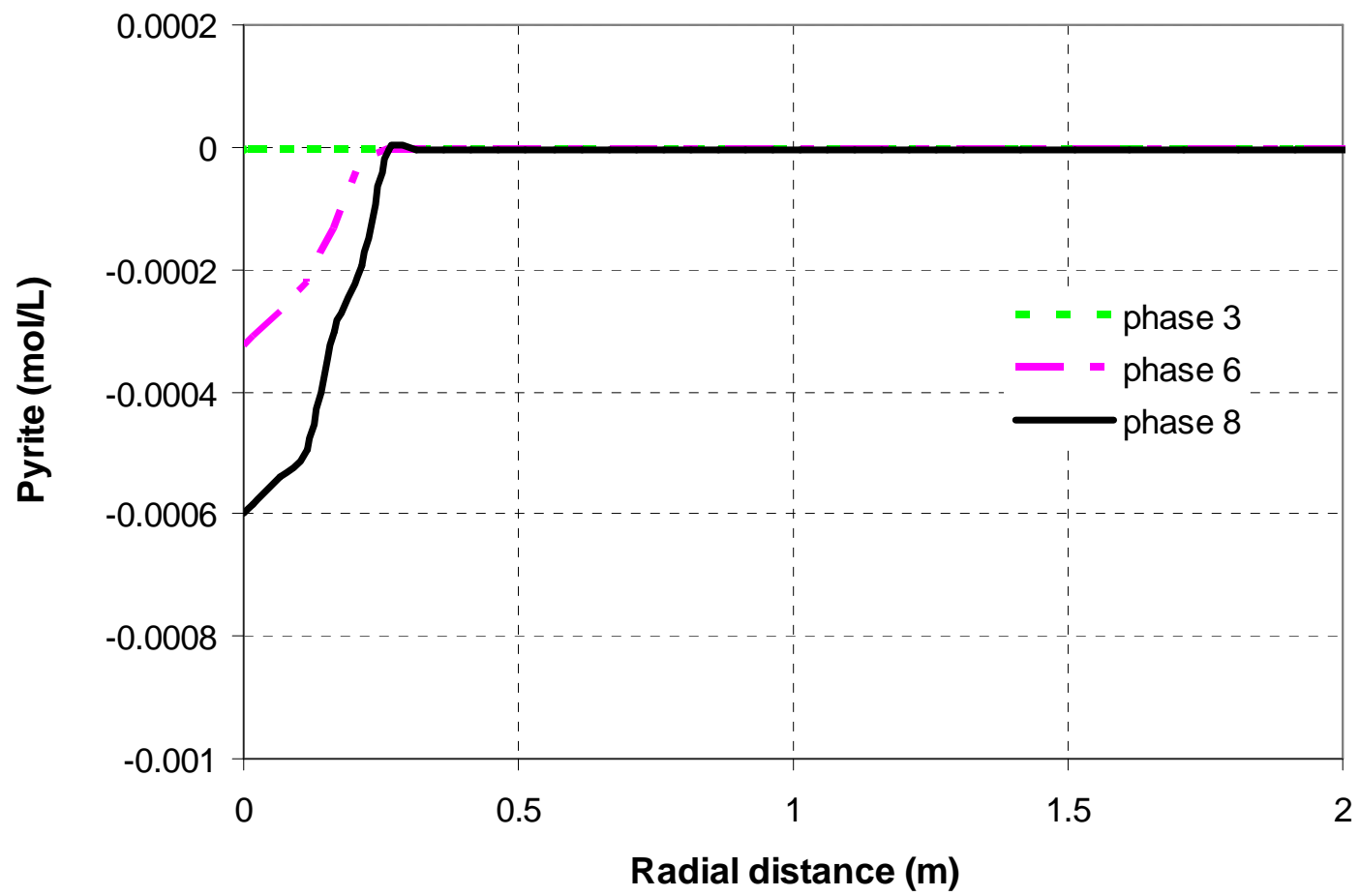

Fig. 11. Spatial distribution of computed cumulative pyrite dissolution at the end of phases 3,6 and 8.

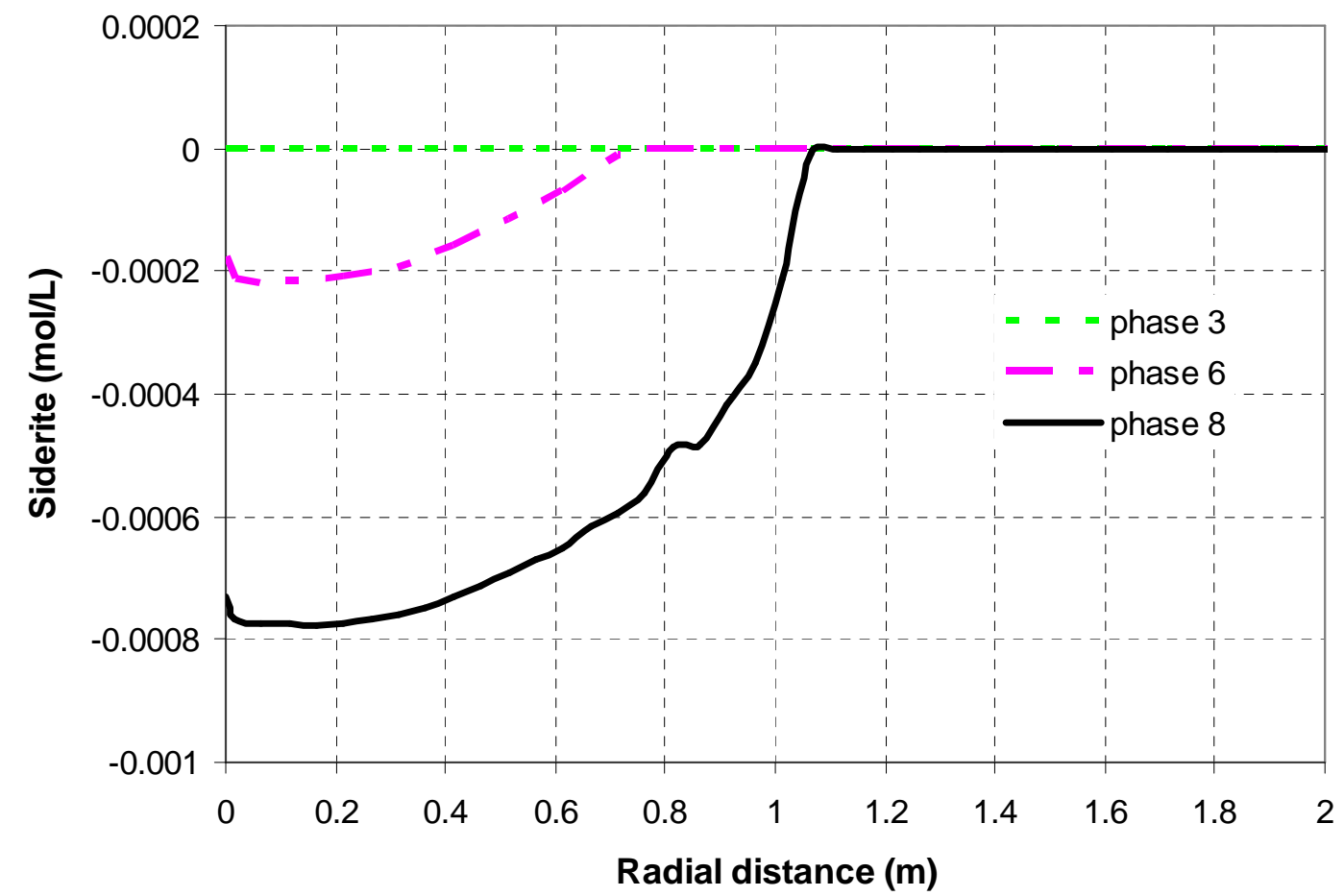

Fig. 12. Spatial distribution of computed cumulative siderite dissolution at the end of phases 3,6 and 8 . 


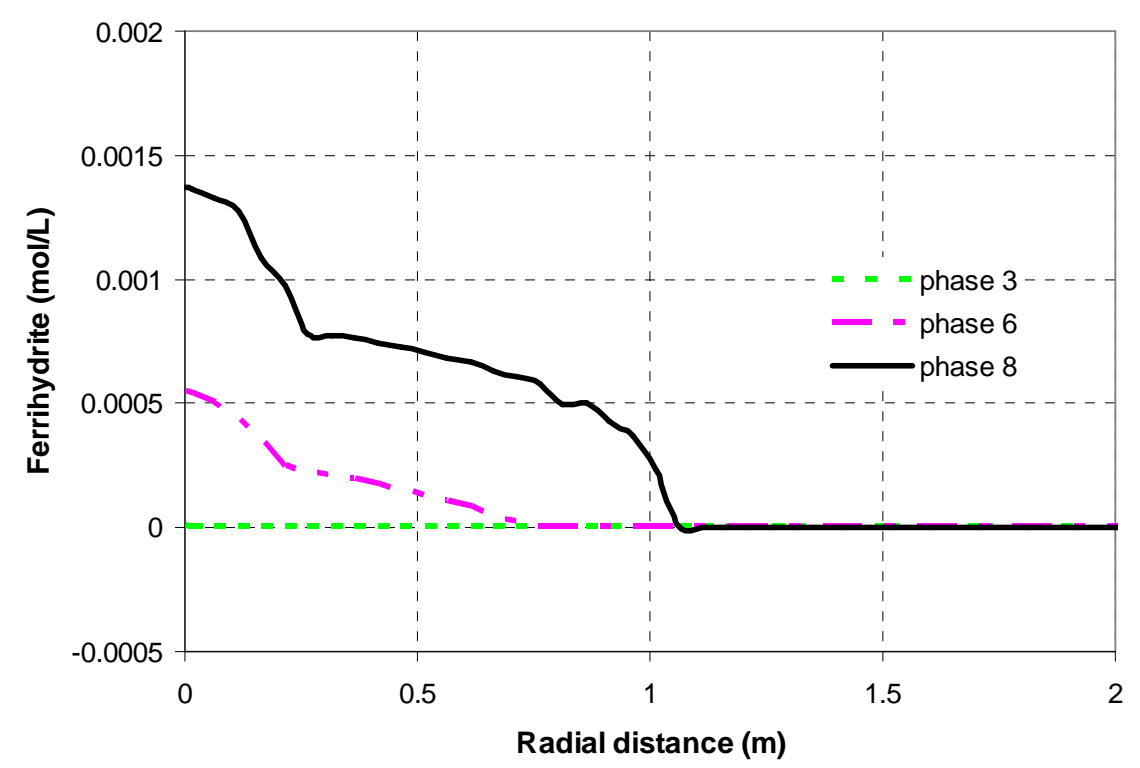

Fig. 13. Spatial distribution of computed cumulative $\mathrm{Fe}(\mathrm{OH})_{3}(\mathrm{~s})$ precipitation at the end of phases 3 , 6 and 8.

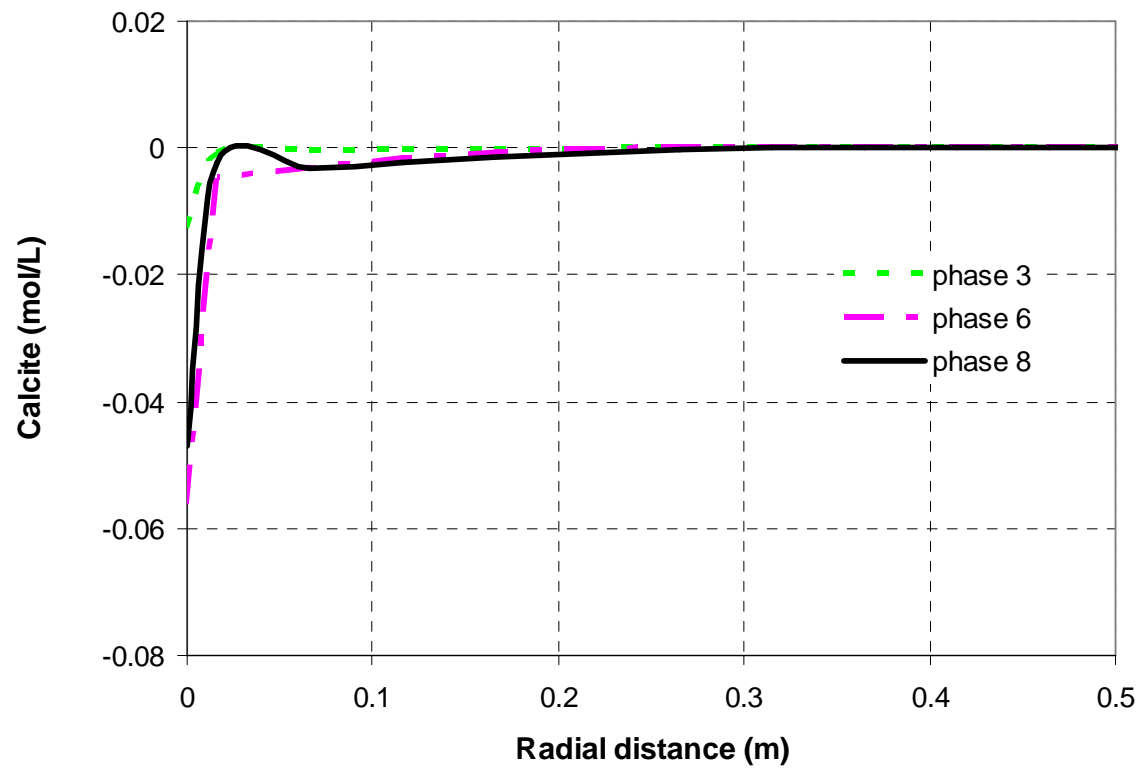

Fig. 14. Spatial distribution of computed cumulative calcite dissolution/precipitation at the end of phases 3, 6 and 8 (negative values for dissolution and positive for precipitation). 


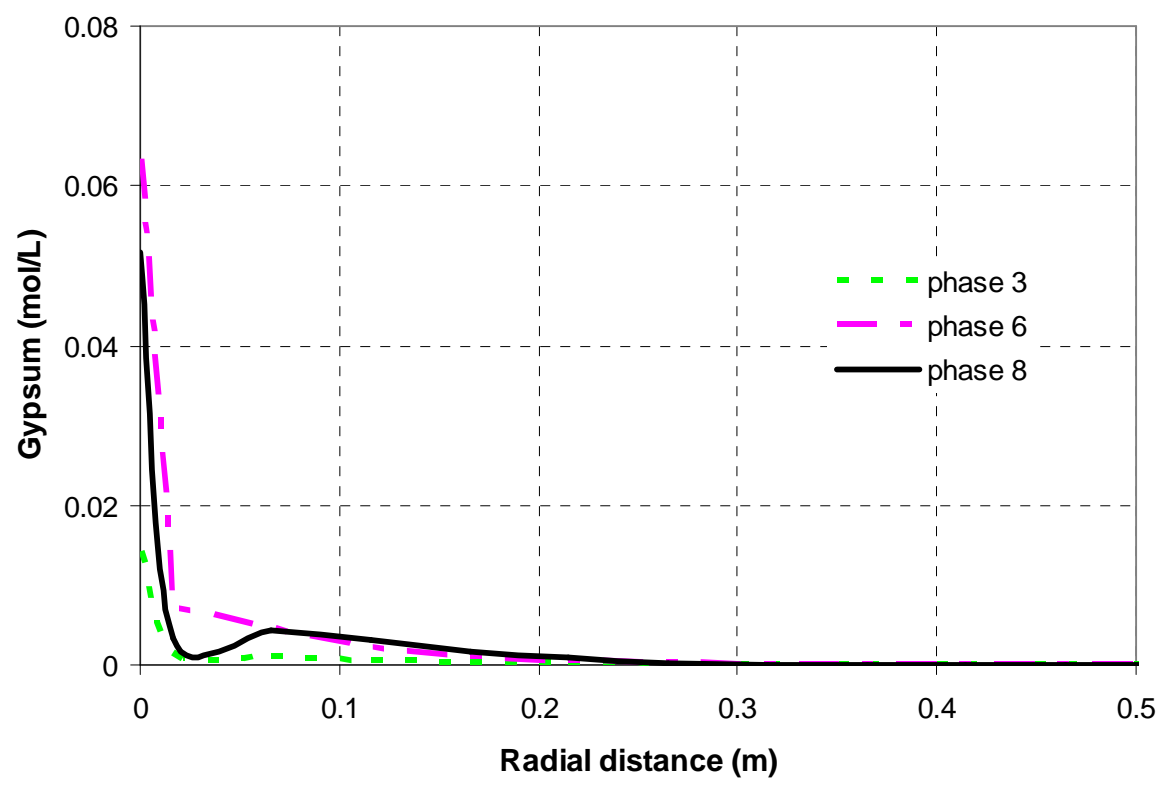

Fig. 15. Spatial distribution of computed cumulative gypsum precipitation at the end of phases 3,6 and 8.

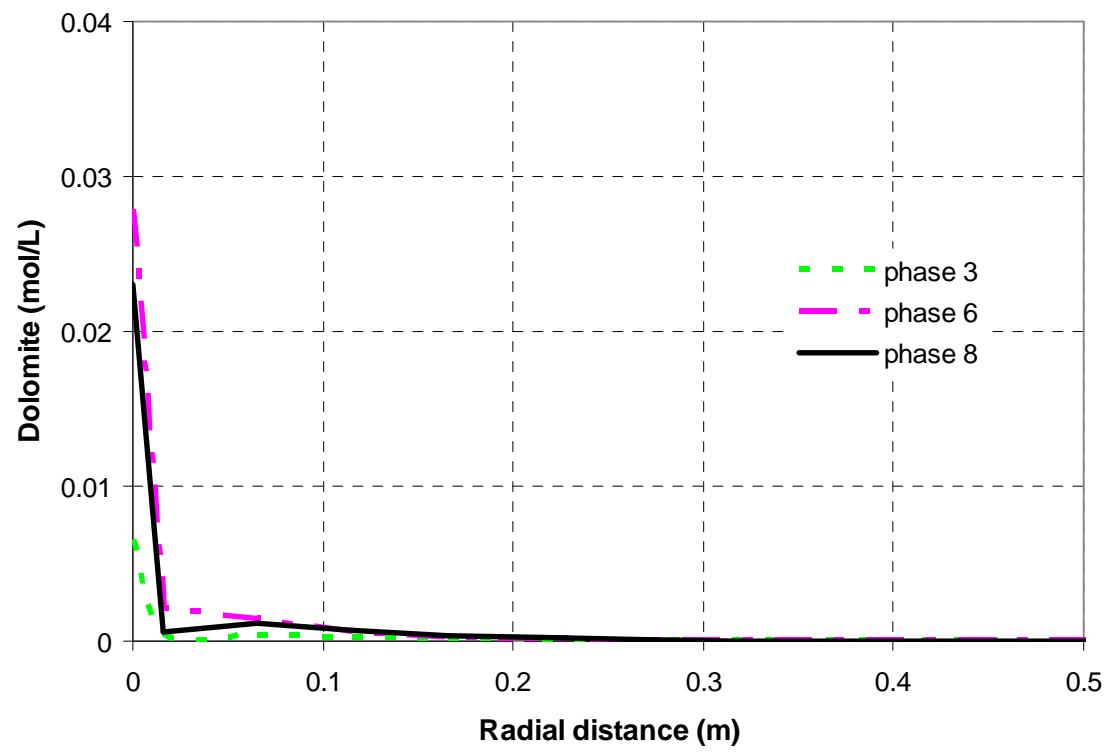

Fig. 16. Spatial distribution of computed cumulative dolomite precipitation at the end of phases 3,6 and 8. 


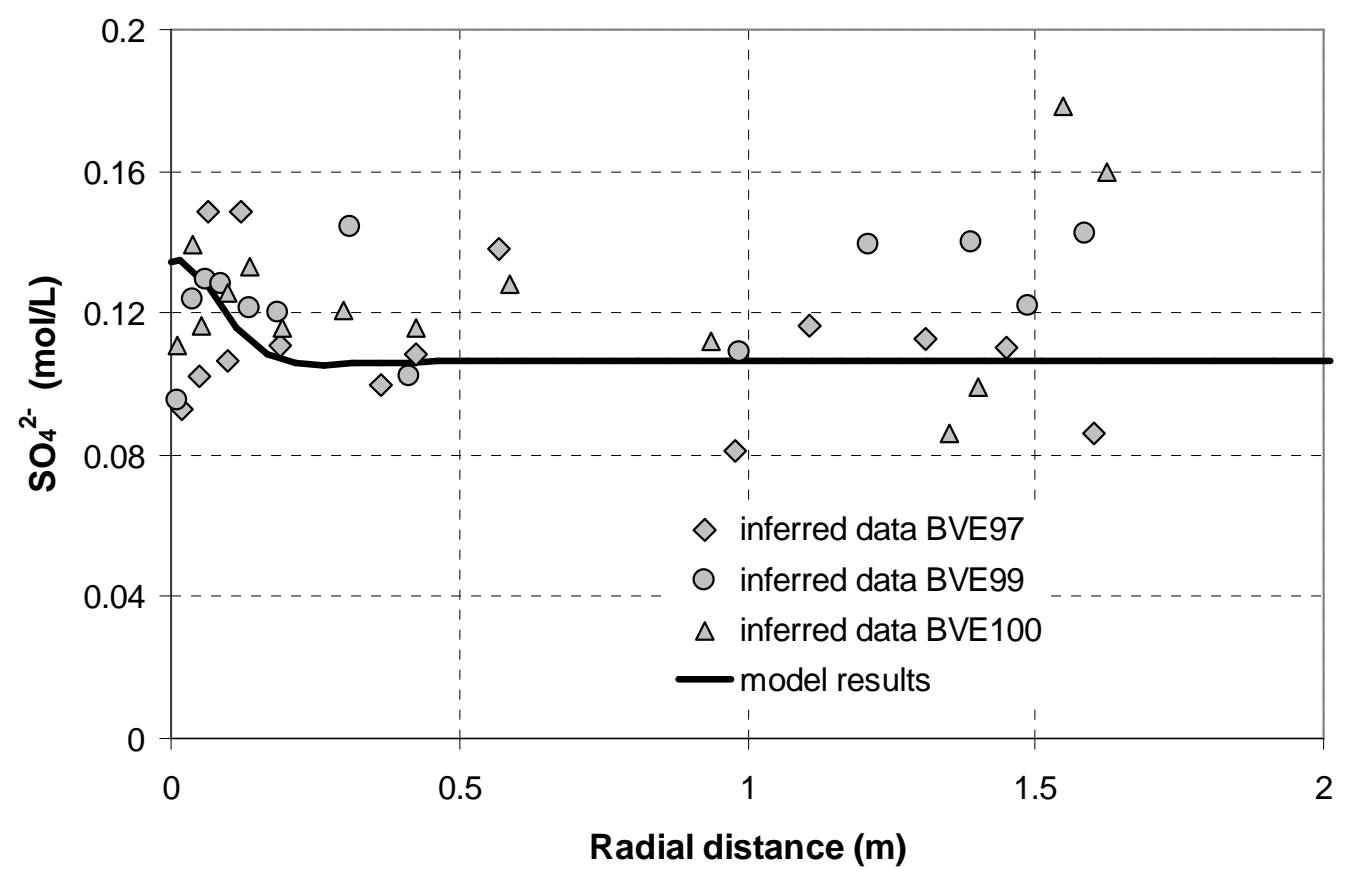

Fig. 17. Spatial distribution of measured and computed $\mathrm{SO}_{4}{ }^{2}$ concentrations after resaturation (phase 8).

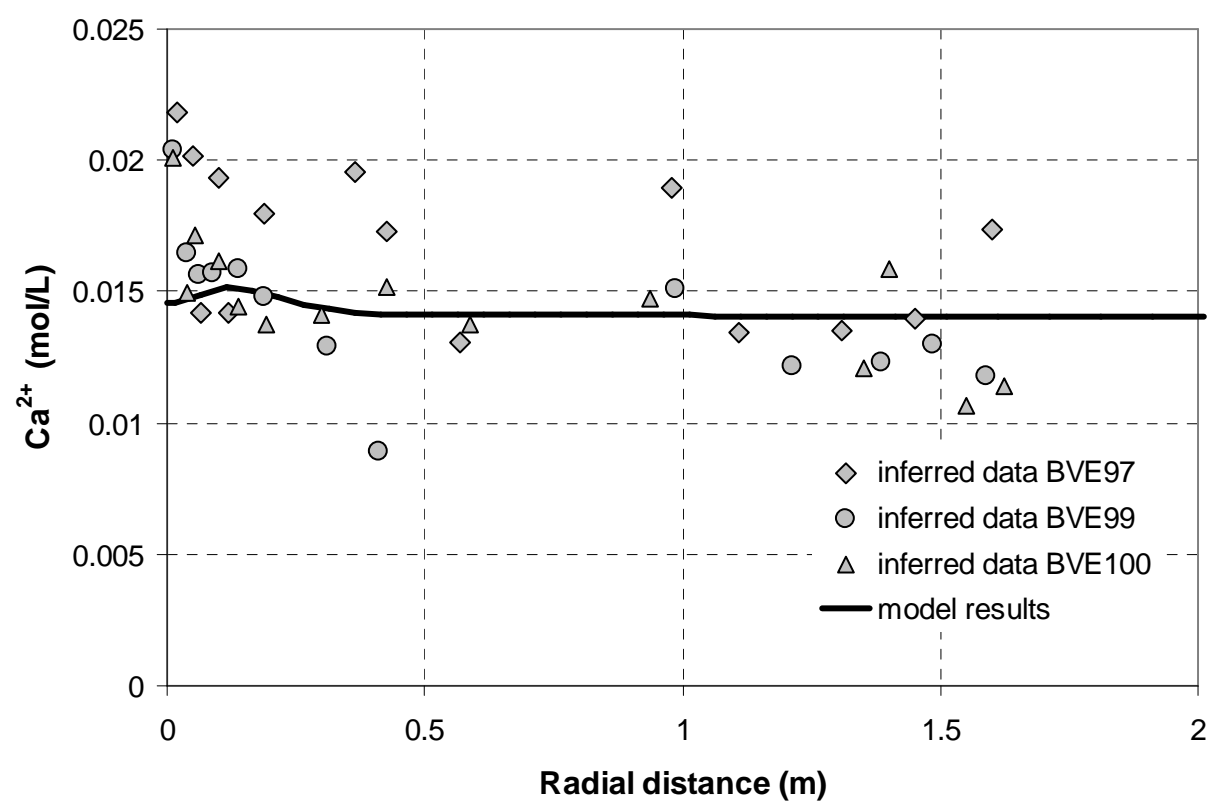

Fig. 18. Spatial distribution of measured and computed $\mathrm{Ca}^{2+}$ concentrations after resaturation (phase 8). 


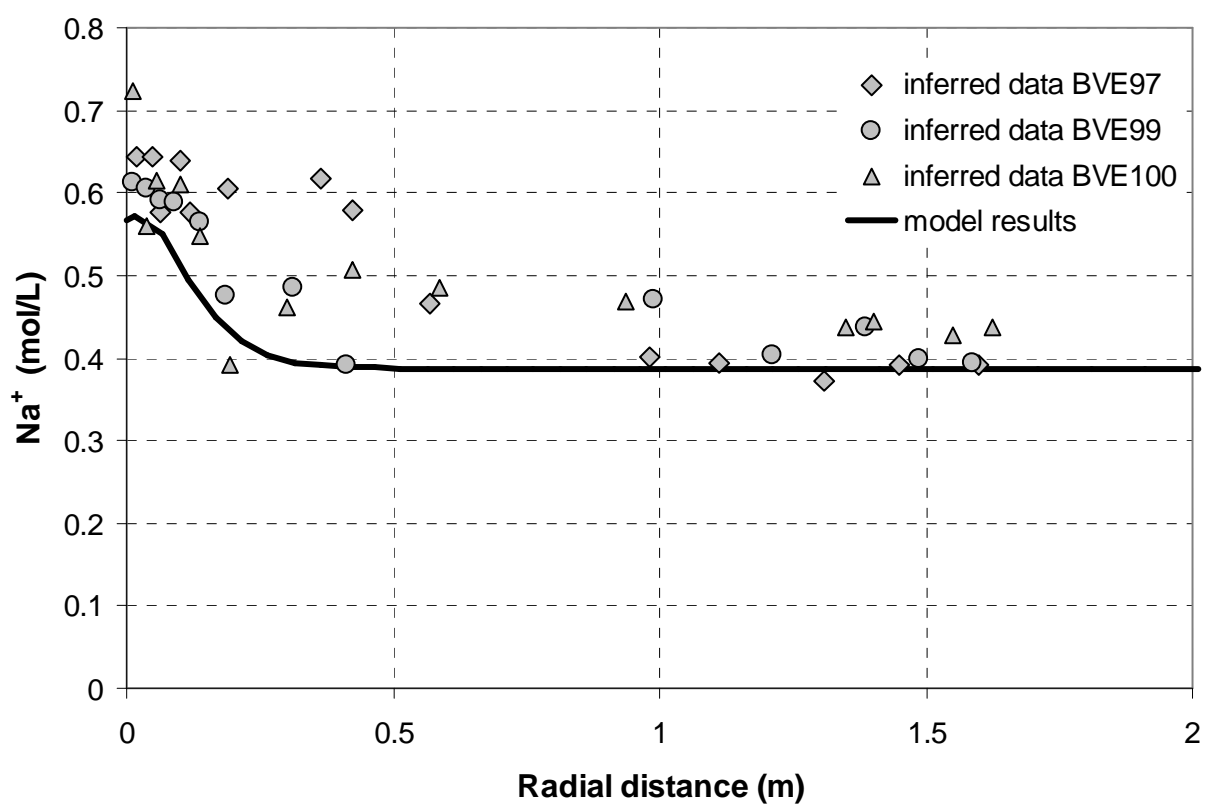

Fig. 19. Spatial distribution of measured and computed $\mathrm{Na}^{+}$concentrations after resaturation (phase

8).

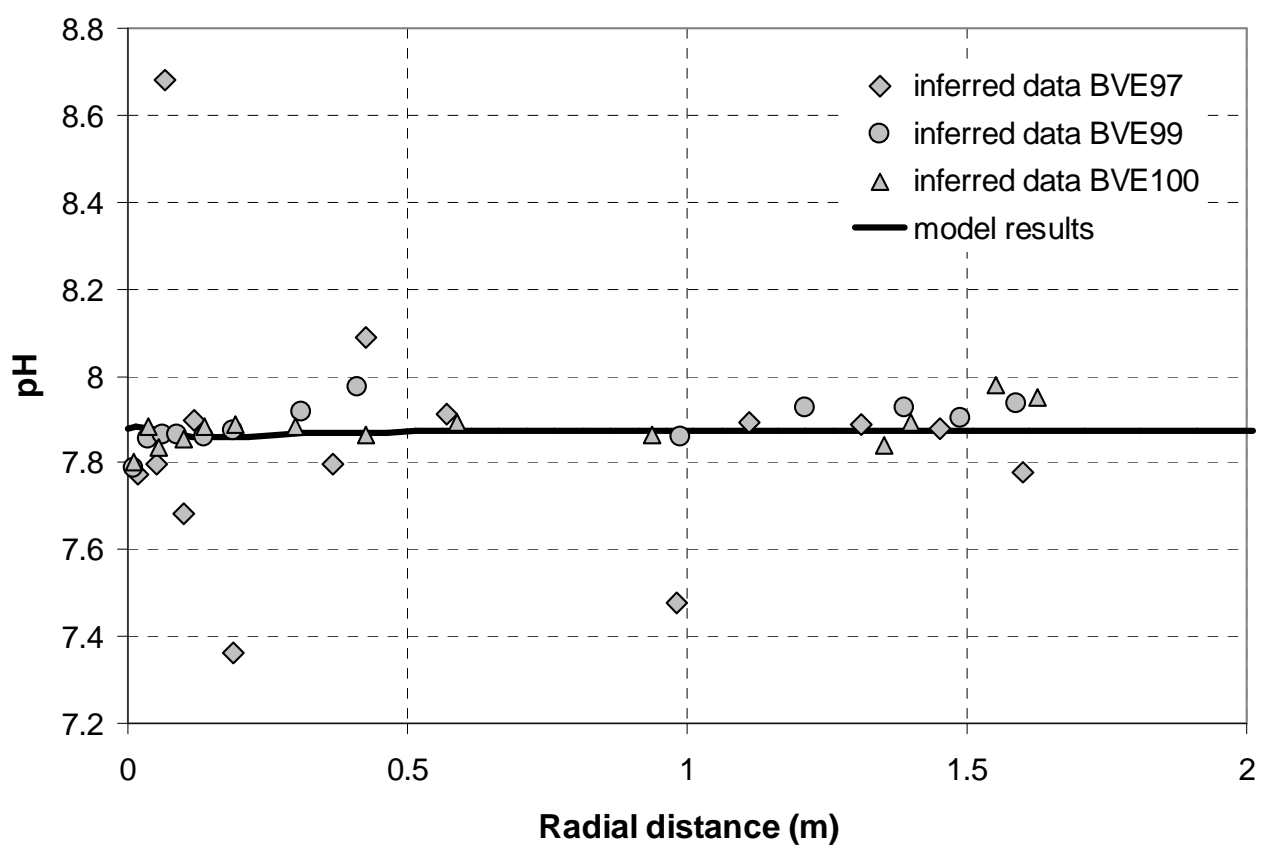

Fig. 20. Spatial distribution of measured and computed $\mathrm{pH}$ after resaturation (phase 8). 


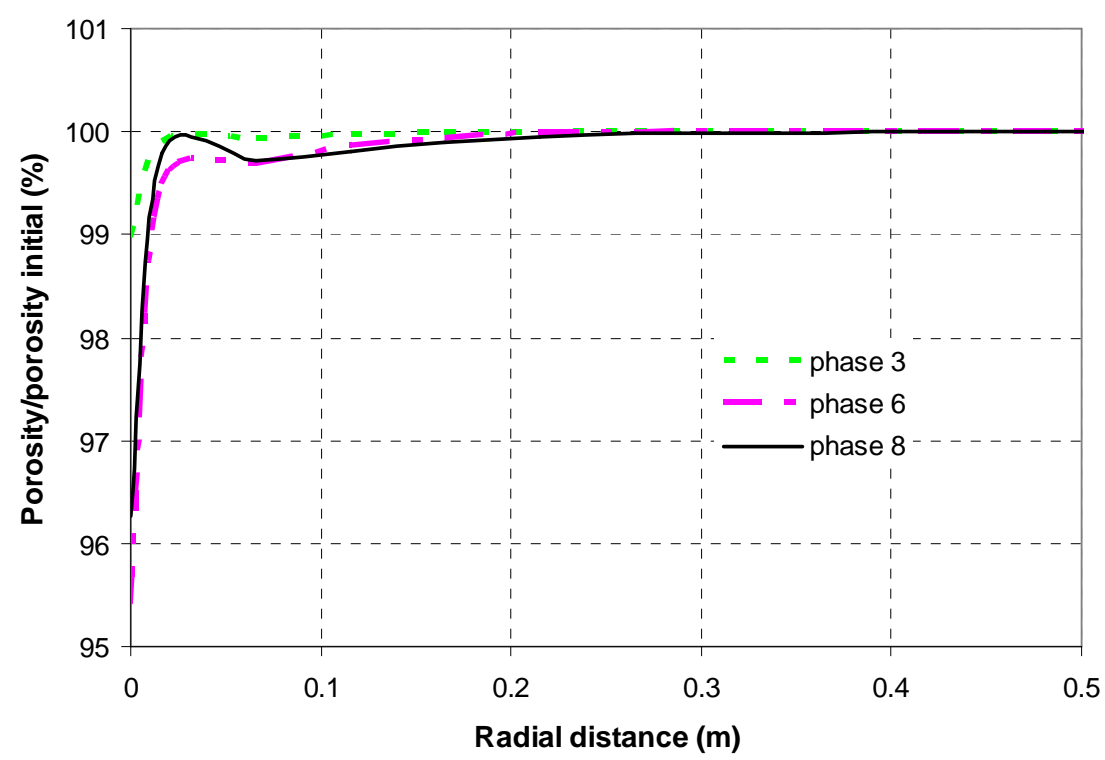

Fig. 21. Spatial distribution of changes in rock porosity at the end of phases 3,6 and 8 .

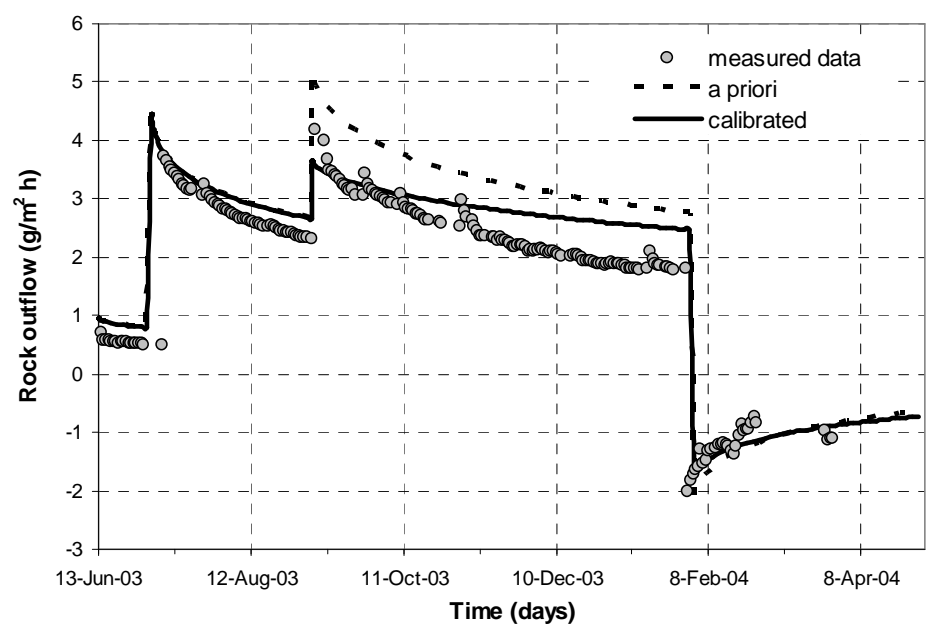

Fig. 22. Sensitivity analysis of rock outflow to changes in the turbulence factor of phases 6 and 7. A priori corresponds to the values of Mayor et al. (2005). Turbulence factors for phases 6 and 7 are listed in Table 1. 


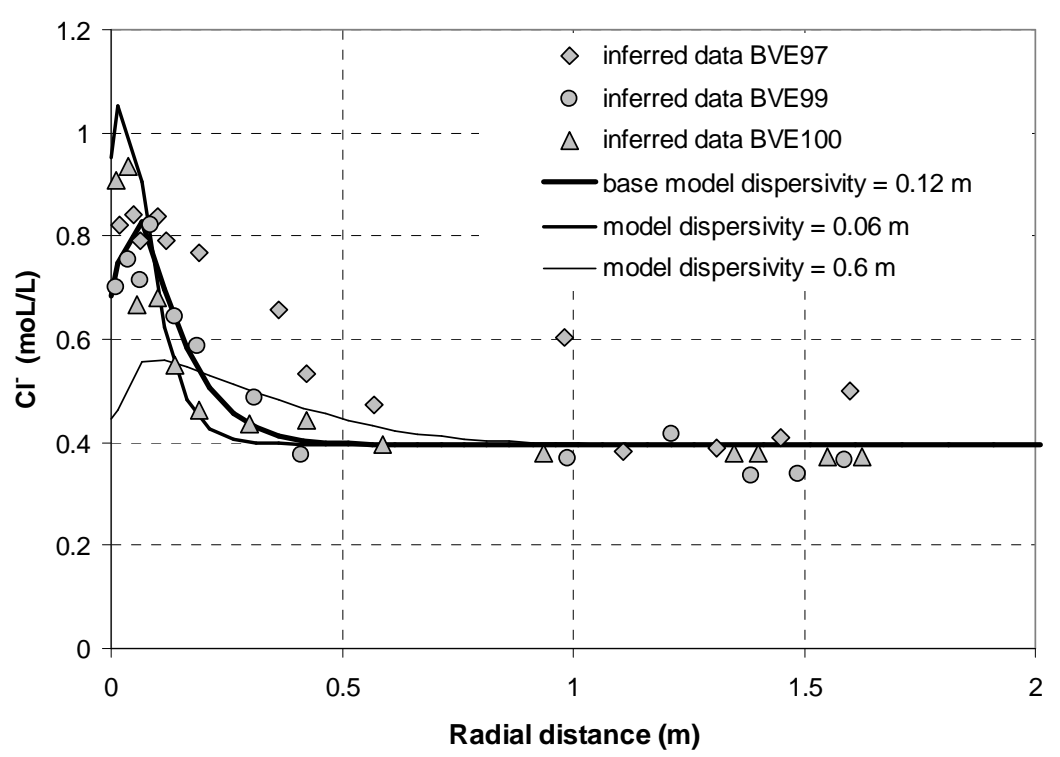

Fig. 23. Sensitivity analysis of $\mathrm{Cl}^{-}$concentrations after resaturation (phase 8) to changes in dispersivity.

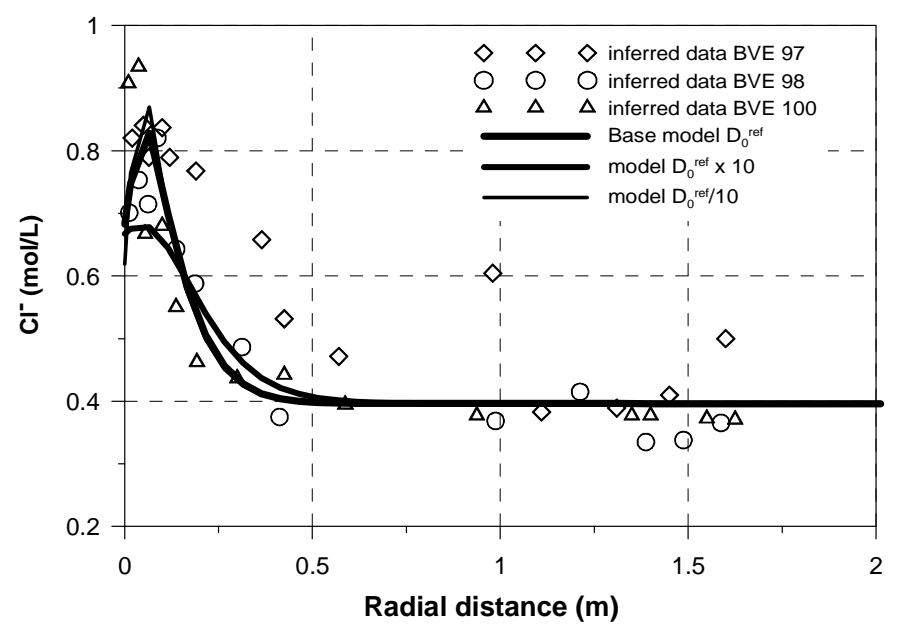

Fig. 24. . Sensitivity analysis of $\mathrm{Cl}^{-}$concentrations after resaturation (phase 8) to changes in molecular diffusion coefficient. 
Table 1. Description, starting date, duration, estimated mean relative humidity of the air in the test section (RH) and turbulence factor, $\beta_{g}$, in Eq. 8 for the phases of the Ventilation Experiment.

\begin{tabular}{|c|c|c|c|c|c|c|c|}
\hline Phases & Period & Description & Starting date & Duration & $\mathrm{RH}^{a}$ & $\begin{array}{c}\beta_{g} \\
\text { Mayor et al. } \\
(2005)\end{array}$ & $\begin{array}{c}\beta_{g} \\
\text { base run }\end{array}$ \\
\hline $1^{\mathrm{st}}$ & \multirow{3}{*}{ Background } & $\begin{array}{l}\text { Microtunnel } \\
\text { excavation }\end{array}$ & February 1999 & $\sim 3.4$ years & $\sim 90 \%$ & $1.25 \times 10^{-4}$ & $1.25 \times 10^{-4}$ \\
\hline $2^{\text {nd }}$ & & $\begin{array}{l}\text { Test section } \\
\text { sealing }\end{array}$ & $\begin{array}{l}1^{\text {st }} \text { August } \\
2002\end{array}$ & $\sim 8$ months & $\sim 93 \%$ & $1 \times 10^{-5}$ & $1 \times 10^{-5}$ \\
\hline $3^{\text {rd }}$ & & Equipment tests & $1^{\text {st }}$ April 2003 & 72 days & $\sim 95 \%$ & $2 \times 10^{-4}$ & $2 \times 10^{-4}$ \\
\hline $4^{\text {th }}$ & \multirow{3}{*}{$\begin{array}{c}\text { First } \\
\text { ventilation }\end{array}$} & $\begin{array}{l}\mathrm{Q}_{\mathrm{in}} \sim 20 \mathrm{~m}^{3} / \mathrm{h} \\
\mathrm{RH}_{\mathrm{in}} \sim 80 \%\end{array}$ & $12^{\text {th }}$ June 2003 & 21 days & $\sim 84 \%$ & $8 \times 10^{-5}$ & $8 \times 10^{-5}$ \\
\hline $5^{\text {th }}$ & & $\begin{array}{l}\mathrm{Q}_{\text {in }} \sim 30 \mathrm{~m}^{3} / \mathrm{h} \\
\mathrm{RH}_{\mathrm{in}} \sim 30 \%\end{array}$ & $3^{\text {rd }}$ July 2003 & $\sim 2$ months & $\sim 47 \%$ & $1 \times 10^{-4}$ & $1 \times 10^{-4}$ \\
\hline $6^{\text {th }}$ & & $\begin{array}{l}\mathrm{Q}_{\text {in }} \sim 30 \mathrm{~m}^{3} / \mathrm{h} \\
\mathrm{RH}_{\mathrm{in}} \sim 1-3 \%\end{array}$ & $\begin{array}{c}4^{\text {th }} \text { September } \\
2003\end{array}$ & $\sim 5$ months & $\sim 15 \%$ & $1 \times 10^{-4}$ & $7 \times 10^{-5}$ \\
\hline $7^{\text {th }}$ & \multirow[b]{2}{*}{ Resaturation } & $\begin{array}{l}\mathrm{Q}_{\text {in }} \sim 20 \mathrm{~m}^{3} / \mathrm{h} \\
\mathrm{RH}_{\mathrm{in}} \sim 100 \%\end{array}$ & $\begin{array}{c}29^{\text {th }} \text { January } \\
2004\end{array}$ & $\sim 1$ month & $\sim 92 \%$ & $5 \times 10^{-4}$ & $4 \times 10^{-4}$ \\
\hline $8^{\text {th }}$ & & $\begin{array}{c}\text { Without } \\
\text { ventilation }\end{array}$ & $1^{\text {st }}$ March 2004 & $\begin{array}{l}\sim 16 \\
\text { months }\end{array}$ & $\sim 95 \%$ & Not reported & $5 \times 10^{-5}$ \\
\hline $9^{\text {th }}$ & $\begin{array}{c}\text { Second } \\
\text { ventilation }\end{array}$ & $\begin{array}{l}\mathrm{Q}_{\mathrm{in}} \sim 40 \mathrm{~m}^{3} / \mathrm{h} \\
\mathrm{RH}_{\mathrm{in}} \sim 1-3 \%\end{array}$ & $1^{\text {st }}$ July 2005 & $\begin{array}{l}\sim 18 \\
\text { months }\end{array}$ & $\sim 15 \%$ & -- & -- \\
\hline
\end{tabular}


Table 2. Equilibrium constants at $15^{\circ} \mathrm{C}$ for aqueous complexes, minerals and gases, and selectivity coefficients for cation exchange reactions used in the geochemical model of the VE.

\begin{tabular}{|c|c|}
\hline Aqueous complexes & $\log \mathrm{K}$ \\
\hline $\mathrm{NaCl}(\mathrm{aq}) \Leftrightarrow \mathrm{Na}^{+}+\mathrm{Cl}^{-}$ & 0.777 \\
\hline $\mathrm{NaSO}_{4}^{-} \Leftrightarrow \mathrm{Na}^{+}+\mathrm{SO}_{4}{ }^{2-}$ & -0.82 \\
\hline $\mathrm{MgSO}_{4}(\mathrm{aq}) \Leftrightarrow \mathrm{Mg}^{2+}+\mathrm{SO}_{4}{ }^{2-}$ & -2.4117 \\
\hline $\mathrm{MgCl}^{+} \Leftrightarrow \mathrm{Mg}^{2+}+\mathrm{Cl}^{-}$ & 0.1349 \\
\hline $\mathrm{CaSO}_{4}(\mathrm{aq}) \Leftrightarrow \mathrm{Ca}^{2+}+\mathrm{SO}_{4}^{2-}$ & -2.111 \\
\hline $\mathrm{NaHCO}_{3}(\mathrm{aq}) \Leftrightarrow \mathrm{Na}^{+}+\mathrm{HCO}_{3}^{-}$ & -0.1541 \\
\hline $\mathrm{CaCl}^{+} \Leftrightarrow \mathrm{Ca}^{2+}+\mathrm{Cl}^{-}$ & 0.695 \\
\hline $\mathrm{MgHCO}_{3}{ }^{+} \Leftrightarrow \mathrm{Mg}^{2+}+\mathrm{HCO}_{3}^{-}$ & -1.0357 \\
\hline $\mathrm{CaHCO}_{3}{ }^{+} \Leftrightarrow \mathrm{Ca}^{2+}+\mathrm{HCO}_{3}^{-}$ & -1.0467 \\
\hline $\mathrm{CaCl}_{2}(\mathrm{aq}) \Leftrightarrow \mathrm{Ca}^{2+}+2 \mathrm{Cl}^{-}$ & 0.6436 \\
\hline $\mathrm{CO}_{2}(\mathrm{aq})+\mathrm{H}_{2} \mathrm{O} \Leftrightarrow \mathrm{H}^{+}+\mathrm{HCO}_{3}^{-}$ & -6.3447 \\
\hline $\mathrm{CaCO}_{3}(\mathrm{aq})+\mathrm{H}^{+} \Leftrightarrow \mathrm{Ca}^{2+}+\mathrm{HCO}_{3}^{-}$ & 7.0017 \\
\hline $\mathrm{MgCO}_{3}(\mathrm{aq}) \Leftrightarrow \mathrm{Mg}^{2+}+\mathrm{CO}_{3}^{-2}$ & 7.3499 \\
\hline $\mathrm{CO}_{3}^{2-}+\mathrm{H}^{+} \Leftrightarrow \mathrm{HCO}_{3}^{-}$ & 10.329 \\
\hline $\mathrm{KSO}_{4}^{-} \Leftrightarrow \mathrm{K}^{+}+\mathrm{SO}_{4}^{2-}$ & -0.8796 \\
\hline $\mathrm{NaCO}_{3}(\mathrm{aq})+\mathrm{H}^{+} \Leftrightarrow \mathrm{Na}^{+}+\mathrm{HCO}_{3}^{-}$ & 9.814 \\
\hline $\mathrm{NaHSiO}_{3}(\mathrm{aq})+\mathrm{H}^{+} \Leftrightarrow \mathrm{Na}^{+}+\mathrm{SiO}_{2}(\mathrm{aq})+\mathrm{H}_{2} \mathrm{O}$ & 8.304 \\
\hline $\mathrm{KCl}(\mathrm{aq}) \Leftrightarrow \mathrm{K}^{+}+\mathrm{Cl}^{-}$ & 1.4946 \\
\hline $\mathrm{FeCO}_{3}(\mathrm{aq})+\mathrm{H}^{+} \Leftrightarrow \mathrm{Fe}^{2+}+\mathrm{HCO}_{3}^{-}$ & 5.5988 \\
\hline $\mathrm{FeSO}_{4}^{-}(\mathrm{aq}) \Leftrightarrow \mathrm{Fe}^{2+}+\mathrm{SO}_{4}^{2-}$ & -2.2 \\
\hline $\mathrm{HSiO}_{3}^{-}+\mathrm{H}^{+} \Leftrightarrow \mathrm{H}_{2} \mathrm{O}+\mathrm{SiO}_{2}(\mathrm{aq})$ & 9.9525 \\
\hline $\mathrm{FeHCO}_{3}(\mathrm{aq}) \Leftrightarrow \mathrm{Fe}^{2+}+\mathrm{HCO}_{3}^{-}$ & -2.05 \\
\hline $\mathrm{OH}^{-}+\mathrm{H}^{+} \Leftrightarrow \mathrm{H}_{2} \mathrm{O}$ & 13.995 \\
\hline $\mathrm{FeCl}^{+} \Leftrightarrow \mathrm{Fe}^{2+}+\mathrm{Cl}^{-}$ & 0.1605 \\
\hline $\mathrm{MgH}_{2} \mathrm{SiO}_{4}(\mathrm{aq})+2 \mathrm{H}^{+} \Leftrightarrow 2 \mathrm{H}_{2} \mathrm{O}+\mathrm{Mg}^{2+}+\mathrm{SiO}_{2}(\mathrm{aq})$ & 17.482 \\
\hline $\mathrm{MgH}_{3} \mathrm{SiO}_{4}^{+}+\mathrm{H}^{+} \Leftrightarrow 2 \mathrm{H}_{2} \mathrm{O}+\mathrm{Mg}^{2+}+\mathrm{SiO}_{2}(\mathrm{aq})$ & 8.5416 \\
\hline $\mathrm{NaOH}(\mathrm{aq})+\mathrm{H}^{+} \Leftrightarrow \mathrm{Na}^{+}+\mathrm{H}_{2} \mathrm{O}$ & 14.18 \\
\hline $\mathrm{CaOH}^{+}+\mathrm{H}^{+} \Leftrightarrow \mathrm{Ca}^{2+}+\mathrm{H}_{2} \mathrm{O}$ & 12.85 \\
\hline $\mathrm{CaH}_{3} \mathrm{SiO}_{4}^{+}+\mathrm{H}^{+} \Leftrightarrow 2 \mathrm{H}_{2} \mathrm{O}+\mathrm{Ca}^{2+}+\mathrm{SiO}_{2}(\mathrm{aq})$ & 18.526 \\
\hline $\mathrm{HSO}_{4}^{-} \Leftrightarrow \mathrm{H}^{+}+\mathrm{SO}_{4}^{2-}$ & -1.9791 \\
\hline $\mathrm{H}_{2} \mathrm{SiO}_{4}{ }^{2-}+2 \mathrm{H}^{+} \Leftrightarrow 2 \mathrm{H}_{2} \mathrm{O}+\mathrm{SiO}_{2}(\mathrm{aq})$ & 22.912 \\
\hline $\mathrm{HCl}(\mathrm{aq}) \Leftrightarrow \mathrm{H}^{+}+\mathrm{Cl}^{-}$ & 0.67 \\
\hline $\mathrm{FeCl}_{2}(\mathrm{aq}) \Leftrightarrow \mathrm{Fe}^{2+}+2 \mathrm{Cl}^{-}$ & 2.454 \\
\hline $\mathrm{KOH}(\mathrm{aq})+\mathrm{H}^{+} \Leftrightarrow \mathrm{K}^{+}+\mathrm{H}_{2} \mathrm{O}$ & 14.46 \\
\hline $\mathrm{FeCl}_{4}^{2-} \Leftrightarrow \mathrm{Fe}^{2+}+4 \mathrm{Cl}^{-}$ & 1.9 \\
\hline $\mathrm{HS}^{-}+2 \mathrm{O}_{2}(\mathrm{aq}) \Leftrightarrow \mathrm{SO}_{4}^{2-}+\mathrm{H}^{+}$ & 138.32 \\
\hline $\mathrm{Fe}^{3+}+0.5 \mathrm{H}_{2} \mathrm{O} \Leftrightarrow \mathrm{H}^{+}+0.25 \mathrm{O}_{2}(\mathrm{aq})+\mathrm{Fe}^{2+}$ & -8.49 \\
\hline Minerals & $\log K$ \\
\hline $\mathrm{SiO}_{2}(\mathrm{~s}) \Leftrightarrow \mathrm{SiO}_{2}(\mathrm{aq})$ & -3.9993 \\
\hline $\mathrm{CaCO}_{3}(\mathrm{~s})+\mathrm{H}^{+} \Leftrightarrow \mathrm{Ca}^{2+}+\mathrm{HCO}_{3}^{-}$ & 1.8487 \\
\hline $\mathrm{FeCO}_{3}(\mathrm{~s})+\mathrm{H}^{+} \Leftrightarrow \mathrm{Fe}^{2+}+\mathrm{HCO}_{3}^{-}$ & -0.192 \\
\hline $\mathrm{CaMg}\left(\mathrm{CO}_{3}\right)_{2}(\mathrm{~s})+2 \mathrm{H}^{+} \Leftrightarrow \mathrm{Mg}^{2+}+\mathrm{Ca}^{2+}+2 \mathrm{HCO}_{3}^{-}$ & 3.5676 \\
\hline $\mathrm{FeS}_{2}(\mathrm{~s})+\mathrm{H}_{2} \mathrm{O}+3.5 \mathrm{O}_{2}(\mathrm{aq}) \Leftrightarrow 2 \mathrm{SO}_{4}{ }^{2-}+\mathrm{Fe}^{2+}+2 \mathrm{H}^{+}$ & 217.4 \\
\hline $\mathrm{CaSO}_{4} \cdot 2 \mathrm{H}_{2} \mathrm{O}(\mathrm{s}) \Leftrightarrow \mathrm{Ca}^{2+}+\mathrm{SO}_{4}{ }^{2-}+2 \mathrm{H}_{2} \mathrm{O}$ & -4.4823 \\
\hline $\mathrm{Fe}(\mathrm{OH})_{3}(\mathrm{~s})+2 \mathrm{H}^{+} \Leftrightarrow 2.5 \mathrm{H}_{2} \mathrm{O}+0.25 \mathrm{O}_{2}(\mathrm{aq})+\mathrm{Fe}^{2+}$ & -2.8344 \\
\hline $\begin{array}{l}\text { Exchanged cations } \\
\end{array}$ & $\overline{\mathrm{K}} \mathrm{Na-cation}$ \\
\hline $\mathrm{Na}^{+}+\mathrm{X}-\mathrm{K} \Leftrightarrow \mathrm{K}^{+}+\mathrm{X}-\mathrm{Na}$ & 0.1995 \\
\hline $\mathrm{Na}^{+}+0.5 \mathrm{X}_{2}-\mathrm{Ca} \Leftrightarrow 0.5 \mathrm{Ca}^{2+}+\mathrm{X}-\mathrm{Na}$ & 0.0792 \\
\hline $\mathrm{Na}^{+}+0.5 \mathrm{X}_{2}-\mathrm{Mg} \Leftrightarrow 0.5 \mathrm{Mg}^{2+}+\mathrm{X}-\mathrm{Na}$ & 0.1256 \\
\hline
\end{tabular}




\begin{tabular}{cc}
$\mathrm{Na}^{+}+0.5 \mathrm{X}_{2}-\mathrm{Sr} \Leftrightarrow 0.5 \mathrm{Sr}^{2+}+\mathrm{X}-\mathrm{Na}$ & 0.0615 \\
\hline Gases & Log $\mathrm{K}$ \\
\hline $\mathrm{O}_{2}(\mathrm{~g}) \Leftrightarrow \mathrm{O}_{2}(\mathrm{aq})$ & -2.8983 \\
$\mathrm{CO}_{2}(\mathrm{~g})+\mathrm{H}_{2} \mathrm{O} \Leftrightarrow \mathrm{H}^{+}+\mathrm{HCO}_{3}{ }^{-}$ & -7.8136 \\
\hline
\end{tabular}


Table 3. Initial total dissolved concentrations (in mol/L) of Opalinus clay pore water in the geochemical model of VE derived (except for dissolved oxygen) from the numerical interpretation of aqueous extract data from samples at $\mathrm{r}>0.8 \mathrm{~m}$. Total dissolved concentration of iron includes all $\mathrm{Fe}(\mathrm{II})$ and $\mathrm{Fe}(\mathrm{III})$ species. The concentration of dissolved $\mathrm{Cl}^{-}$corresponds to no anion exclusion.

\begin{tabular}{||c|c||}
\hline $\mathrm{pH}$ & 7.9 \\
\hline $\mathrm{O}_{2}(\mathrm{aq})$ & $4.3 \times 10^{-51}$ \\
\hline $\mathrm{Cl}^{-}$ & $2.14 \times 10^{-1}$ \\
\hline $\mathrm{HCO}_{3}{ }^{-}$ & $6.95 \times 10^{-4}$ \\
\hline $\mathrm{SO}_{4}{ }^{2-}$ & $1.07 \times 10^{-1}$ \\
\hline $\mathrm{Na}^{+}$ & $3.88 \times 10^{-1}$ \\
\hline $\mathrm{K}^{+}$ & $9.35 \times 10^{-3}$ \\
\hline $\mathrm{Ca}^{2+}$ & $1.43 \times 10^{-2}$ \\
\hline $\mathrm{Mg}^{2+}$ & $1.24 \times 10^{-2}$ \\
\hline $\mathrm{Fe}^{2}$ & $1.17 \times 10^{-5}$ \\
\hline $\mathrm{SiO}_{2}(\mathrm{aq})$ & $6.16 \times 10^{-5}$ \\
\hline
\end{tabular}


Table 4. Initial volume fraction of minerals used in the geochemical model of the VE (Pearson et al., 2003).

\begin{tabular}{|c|c|c|c|c|c|c||}
\hline Quartz & Calcite & Siderite & Dolomite & Pyrite & Gypsum & Ferrihydrite \\
\hline 0.06 & 0.28 & 0.04 & 0.02 & 0.02 & 0 & 0 \\
\hline
\end{tabular}

